CUADERNOS DE ESTUDIOS GALLEGOS, LX Núm. 126 (enero-diciembre 2013), págs. 171-223

ISSN: 0210-847 X

DOI: 10.3989/ceg.2013.126.05

\title{
EL TESTAMENTO DEL MARISCAL PARDO DE CELA. NOTICIA DEL HALLAZGO Y EDICIÓN DEL DOCUMENTO*
}

\author{
Eduardo Pardo de Guevara y Valdés \\ Instituto de Estudios Gallegos "Padre Sarmiento" \\ CSIC-Xunta de Galicia
}

\footnotetext{
* El presente artículo es fruto de las investigaciones desarrolladas en el contexto del proyecto Linaje, parentela y poder: la pirámide nobiliaria gallega (siglos XIII al XV) I (HAR2010-18378), cuyo Investigador Principal es quien esto escribe.
} 


\title{
EL TESTAMENTO DEL MARISCAL PARDO DE CELA. NOTICIA DEL HALLAZGO Y EDICIÓN DEL DOCUMENTO
}

\begin{abstract}
RESUMEN
Las investigaciones en torno a la figura y los hechos del mariscal Pardo de Cela —uno de los protagonistas más señalados y debatidos de la segunda mitad del siglo XV gallego- han logrado en estas dos últimas décadas avances notables; el más reciente y significativo ha sido la localización de su testamento y codicilo, otorgados el 1 y 3 de octubre de 1483, justo antes de su ejecución pública en la plaza mayor de Mondoñedo. En estas páginas se da cuenta de este hallazgo y se contextualiza, valora y edita el propio documento, conservado en tres traslados notariales insertos en el largo proceso que sostuvieron, entre 1510 y 1542, varios descendientes del personaje con los obispos de Mondoñedo, sobre la posesión de las terrerías de Sargadelos, San Romao, Regueira de Ferrol y Cervo.

Palabras Clave: Historia social de la nobleza, edición de fuentes documentales, Baja Edad Media, Galicia, testamento, mariscal Pardo de Cela.
\end{abstract}

\section{O TESTAMENTO DO MARISCAL PARDO DE CELA. NOTICIA DO ACHADO E EDICIÓN DO DOCUMENTO}

\section{Resumo}

As investigacións en torno á figura e os feitos do mariscal Pardo de Cela —un dos protagonistas máis sinalados e debatidos da segunda metade do século XV galego— lograron nestas dúas últimas décadas avances notables; o máis recente e significativo foi a localización do seu testamento e codicilo, outorgados o 1 e 3 de outubro de 1483, xusto antes da súa execución pública na praza maior de Mondoñedo. Nestas páxinas anúnciase este achado e contextualizase, valora e edita o propio documento, conservado en tres traslados notariais insertos no longo proceso que sostiveron, entre 1510 e 1542, varios descendentes do personaxe cos bispos de Mondoñedo, sobre a posesión das terrerías de Sargadelos, San Romao, Regueira de Ferrol e Cervo.

Palabras Clave: Historia social da nobreza, edición de fontes documentais, Baixa Idade Media, Galicia, testamentos, mariscal Pardo de Cela.

\section{LAST WILL AND TESTAMENT OF MARSHAL PARDO DE CELA. INFORMATION ABOUT THE FINDING AND TRANSCRIPTION OF THE DOCUMENT}

\begin{abstract}
Research into the figure and the activities of Marshal Pardo de Cela —one of the most well-known and controversial protagonists of the second half of the $15^{\text {th }}$ century in Galicia - has progressed remarkably in the last two decades. The most recent and significant breakthrough has been the discovery of his last will and testament and codicil; they were signed on $1^{\text {st }}$ and $3^{\text {rd }}$ Octuber 1483, just before his public execution in the main square of Mondoñedo.

In the present article we describe this finding and we contextualize, evaluate and publish the content of the document itself. It was included in three notarial copies, which were part of a lengthy legal process between several of his descendents and the bishops of Mondoñedo, from 1510 to 1542, regarding the ownership of the "terrerias" of Sargadelos, San Romao, Regueira de Ferrol and Cervo. KEY WORDS: Social History of the Nobility, publication of documentary sources, Late Middle Ages, Galicia, wills of testament, Marshal Pardo de Cela.
\end{abstract}


Recibido/Received: 01/07/2013

Aceptado/Accepted: 19/08/2013

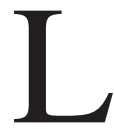

a imposibilidad de avanzar con pasos nuevos y seguros en el conocimiento de la figura del mariscal Pardo de Cela, a partir cuanto menos de las fuentes ya conocidas, me convenció hace ya bastantes años de la necesidad de perseverar en la búsqueda de nuevos recursos heurísticos. De ahí, claro, la atención que he procurado dedicar a esto último, evitando al propio tiempo seguir incidiendo en el debate historiográfico, por más que la reiterada insistencia de algunos interesados en el asunto haya hecho que violentara en lugares y ocasiones muy contadas esta firme y prudente determinación ${ }^{1}$. Como fácilmente puede comprenderse, la razón de mi interés no es otro que penetrar en los secretos que todavía encierran aquellos acontecimientos, no para disipar la atractiva leyenda que desde hace siglos envuelve al personaje y cuya pervivencia se justifica precisamente en esa antigüedad, sino para moderar con la verdad de los documentos la interesada imaginación de algunos de sus devotos; me refiero, en particular, a los que todavía hoy insisten en juzgar de forma ligera y sesgada - sobre todo sesgada - las circunstancias y triste final de quien fue uno de los más caracterizados protagonistas de la segunda mitad del siglo XV gallego².

En este contexto creo necesario resaltar, aunque sea sumariamente, que las investigaciones en torno a la figura de Pardo de Cela y su época han logrado en estas dos últimas décadas muchos y muy notables avances. Menciono, a modo sólo de ilustración, todo lo que afecta a la personalidad social del personaje, tal

\footnotetext{
1 Véanse, por ejemplo, Eduardo Pardo de Guevara y Valdés, "El mariscal Pardo de Cela. Una injusticia ejemplar", Torre de los Lujanes, 55 (2005), págs. 83-108, y "El mariscal Pardo de Cela. Leyenda, mito y realidad", en M. Alfonso Valín Valdés et al. (coord.), O Mariscal Pardo de Cela e o seu tempo. I Xornadas de Historia medieval da Mariña Lucense, Lugo, Diputación provincial, 2006, págs. 1-63.

2 Los despropósitos, aunque a veces lleguen a gozar de cierta aceptación y eco a fuerza de ser repetidos, no dejan de ser eso exactamente. Un ejemplo reciente y extremo, pero ya manido, es el que pretende situar al Mariscal Pardo de Cela no marco dunha insurreción galega xeralizada e a persistencia dunha vontade aínda moi firme a finais do século XV de dotar a Galiza dunha estrutura de Estado segregado da órbita dos Trástamara a pesar das altas cotas de soberanía das que dispoñía o país. Véase, Xosé Ramón Ermida Meilán, "Pardo de Cela, un capítulo da revolta galega”, en Terra e tempo, 10 de septiembre de 2013.
} 
como el origen, desarrollo y atomización de sus dos estirpes de procedencia o la compleja clarificación de todo su entorno parental y señorial, sobre lo que también han trabajado con éxito - lo sé muy bien- algunos conocidos investigadores, como Fernando Dopico o José Carlos Breijo, sin olvidar naturalmente el contexto político y las circunstancias mismas de los grandes acontecimientos de aquellos años, tal como la rebelión irmandiña, la guerra civil o la posterior pacificación del reino, uno de cuyos hechos culminantes fue precisamente su propia prisión y muerte ${ }^{3}$. Puede decirse muy bien, por consiguiente, que es mucho lo que hoy se sabe fehacientemente sobre la figura y sus hechos, bastante más desde luego de lo que cabría referir respecto a algunos otros contemporáneos suyos igualmente destacados. Pero es comprensible que nada de esto resulte suficiente en el caso del mariscal Pardo de Cela, pues no puede ni debe obviarse su singular dimensión histórica, forjada en gran medida a partir del extraordinario eco de su ejecución pública en la plaza mayor de Mondoñedo. Por eso, precisamente, la localización del testamento y codicilo que otorgó en esta misma ciudad el 1 y 3 de octubre de 1483, creo que debe ser valorado sólo como un nuevo paso - aunque significativo e importante sin duda - en el curso de una investigación de más largo recorrido y precisa, todavía, de continuidad... De momento, al menos, cumple reconocer que el contenido de este nuevo documento no ofrece todas las respuestas que cabía esperar y que tanto el asunto como los interesados reclaman, aunque algunas sí parecen intuirse con cierta nitidez. En el horizonte inmediato, por consiguiente, además de la necesaria recapitulación y puesta al día de la información nueva o inédita, de carácter sobre todo genealógico, comienzan a perfilarse también otros importantes retos; entre ellos no es desmesura confiar en la localización del proceso y de la consiguiente sentencia judicial que condenó al Mariscal, de todo lo cual parece que existía una copia en manos de sus familiares.

Como ya he recordado en más de una ocasión, la primera noticia relativa a la existencia de un testamento otorgado por el mariscal Pardo de Cela me llegó a mediados de los años ochenta a través de un viejo y querido amigo, Santiago Fernández Muras Sagastizábal, vástago de los Pardo de Cela vivarienses y uno de los

\footnotetext{
3 El resultado de mis investigaciones en torno a estos acontecimientos está recogido en los tres capítulos correspondientes de la obra colectiva Os Capítulos da Irmandade. Peregrinación y conflicto social en la Galicia del siglo XV, Xunta de Galicia, Santiago de Compostela, 2006 ("La rebelión irmandiña. Conexiones, hechos y documentos", págs. 384-411; "La pacificación de Galicia por los Reyes Católicos. El hecho que Zurita llamó la doma y castración del Reino de Galicia”, págs. 438-465; "Fonseca, Moscoso... y el Rey. A propósito de la accidentada peregrinación de León de Romisthal, barón de Blatna", págs. 484-501). Más recientemente, en Eduardo PARDO DE GuEvarA Y VALDÉs, De linajes, parentelas y grupos de poder. Aportaciones a la historia social de la nobleza bajomedieval gallega, Madrid, Fundación Cultural de la Nobleza Española y CSIC, 2012, págs. 405-512.
} 
más asiduos e incansables investigadores que frecuentaban el AHN por aquellos años; se trataba de una detallada referencia del siglo XVII, o no muy posterior, al largo pleito que a partir de 1510 habían sostenido Bernaldino de Castellanos y su mujer, doña Mayor de Vaamonde, con la iglesia mindoniense sobre la posesión de diversas terrerías, en la cual se decía que las partes litigantes habían presentado varias copias de aquel instrumento ${ }^{4}$. Como es natural, la localización de este proceso se convirtió a partir de aquel momento en uno de los objetivos prioritarios de mis investigaciones, sin sospechar en modo alguno por entonces — todavía no existía el recurrido PARES - que la búsqueda habría de resultar finalmente larga y ardua... El primer paso decisivo se produjo hacia 1995 o 1996, cuando conseguí localizar en el Archivo de la Real Chancillería de Valladolid la ejecutoria del aludido pleito, en total 33 folios escritos en sus dos caras, cuyo contenido consideré en aquel momento muy importante y novedoso; de ahí que procediera a estudiarlo con detalle y me ocupara asimismo de su transcripción, al objeto de proceder después a una correcta edición y comentario del mismo ${ }^{5}$. Sin embargo, los años pasaron rápidamente y, al fin, este largo documento quedó sin divulgar por razones y circunstancias de muy diverso signo; entre ellas, supongo, mis otras ocupaciones y estudios, así como el deseo — probablemente no muy consciente- de completar la investigación con nuevos hallazgos y sobre todo con el del propio proceso, donde deberían estar los documentos de prueba — entre ellos las aludidas copias del testamento y codicilo - y las consabidas deposiciones de los testigos. Aunque a lo largo de los años siguientes seguí empeñado en esta búsqueda, lo cierto es que no logré el éxito que apetecía: el problema, como supe después, radicaba en que las ejecutorias y los pleitos o procesos correspondientes son unidades archivísticas diferentes e independientes... Sin embargo, parafraseando a Ramón y Cajal, el azar afortunado premió al fin mi perseverancia: en el curso de una conversación que mantuve en Santiago de Compostela con Cristina Emperador, directora del Archivo de la Real Chancillería de Valladolid, allá por el mes de junio de 2011, surgió incidentalmente el asunto de mi interés y, de seguido, el ruego de su intervención para que se cruzaran los datos y referencias que obraban en mi poder y se procurara localizar así lo que yo estaba buscando desde tanto tiempo atrás; recuerdo,

\footnotetext{
${ }^{4}$ Noticia de esta referencia y alusión al inicio de la búsqueda del testamento en Eduardo PARDO DE Guevara y Valdés, "Documentos medievales de Betanzos (I). Los Pardo de Cela del siglo XV", Anuario Brigantino, 9 (1986), págs. 23-30.

5 Archivo de la Real Chancillería de Valladolid (en adelante sólo ARCHV), Sección de Reales Ejecutorias, leg. 565-1. Una referencia anterior en Lino Canedo, "Guevara, obispo de Mondoñedo", Archivo Ibero-Americano. Estudios acerca de Fray Antonio de Guevara en el IV centenario de su muerte, 6 (abril-septiembre.1946), pág. 307. Se cita también, aunque mucho después, en Enrique Cal Pardo, Episcopologio Mindoniense, Santiago de Compostela, Instituto de Estudios Gallegos "Padre Sarmiento", CSIC-XuGa, 2003 (Cuadernos de Estudios Gallegos. Anejo, 23), pág. 295.
} 
con impagable gratitud, que en apenas unas pocas semanas, por los primeros días del mes de julio, recibí al fin la gratísima noticia de la localización del expediente aparentemente completo — un legajo con más de un millar de páginas, sin numeración correlativa y cosido en mazos desordenados- y, dentro de él, los diferentes documentos de prueba aportados por las partes. Entre estos últimos se encuentran, como preveía, los tres traslados notariales del testamento y codicilo otorgados por el mariscal Pardo de Cela en la fecha y lugar ya indicados más arriba ${ }^{6}$.

El caudal informativo de este importante documento es naturalmente más que estimable, aunque resulta un tanto limitado en lo que afecta al asunto central que es motivo del debate historiográfico. En cualquier caso, lo más destacable no está tanto en su contenido como en el hecho mismo de su otorgamiento y, más que esto, en su propia significación histórica, que considero más que notable. Esto último y la natural expectación que la noticia de su hallazgo ha despertado me inclinan a no retrasar más la edición de los tres traslados del testamento y codicilo, posponiendo para mejor ocasión —en contra de lo que pretendía en un primer momento - una relectura sosegada de la información que contiene y a la que incorporaré los otros instrumentos y noticias relevantes que he logrado recopilar en el curso de mis recientes investigaciones sobre el mariscal Pardo de Cela ${ }^{7}$.

\section{EL CONTEXTO ARCHIVÍSTICO Y DOCUMENTAL}

El proceso, en el que se encuentran insertos los dichos tres traslados del testamento y codicilo, no deja de ser — conviene advertirlo — un testimonio más en el contexto del largo rosario de iniciativas, reclamaciones, procesos judiciales o simples debates, que tras la ejecución del mariscal Pardo de Cela debieron afrontar sus herederos en defensa de los bienes confiscados, o a veces directamente usurpados, a raíz de aquel acontecimiento. El asunto es bien conocido, como ha sido resaltado en múltiples ocasiones, y sus huellas en los archivos públicos son afortunadamente ricas y variadas.

\footnotetext{
6 ARCHV, Pleitos Civiles. Escribanía de Alonso Rodríguez (F). Caja 2595-1. El lector deberá tener en cuenta que la numeración que aquí se utilizará en las referencias no remite al manuscrito original, sin paginar, sino a su copia digitalizada: en total, 1190 imágenes.

7 El hallazgo se produjo en la fecha indicada en el texto y fue conocido sólo por los miembros del equipo de investigación del proyecto de referencia y dos investigadores interesados en la figura de Pardo de Cela (José Carlos Breijo y Fernando Dopico). Pasado el tiempo y una vez estudiado y valorado el expediente completo, el 22 de enero último se consideró oportuno dar a conocer la noticia en una rueda de prensa, a la que también concurrieron - en representación de la Xunta de Galicia- el conselleiro de Cultura, Educación y Ordenación Universitaria, Xesús Vázquez Abad, y el secretario general de Cultura, Anxo Lourenzo; unos días después, el 2 de febrero, se celebró en la sede del IEGPS un acto académico en el que intervinieron P. Otero Piñeyro Maseda, C. González Paz y yo mismo, haciendo la lectura pública del documento I. García Tato.
} 
El origen de este pleito, en particular, parece estar en la queja presentada ante el mayordomo y el provisor del obispo de Mondoñedo, el 11 de diciembre de 1503, por Bernaldino de Castellanos, corregidor de Vivero, en nombre de su mujer doña Mayor de Vaamonde ${ }^{8}$, por haberles sido retenidas ciertas cargas de pan de las terrerías Sargadelos, San Romao de Vilaestrofe, Regueyra de Ferrol y Cervo. Esta medida había respondido a la pretensión del Obispo, que las consideraba propias de su mesa episcopal, por cuanto en un testamento oreginal synado de Pero López, notario, que pareze que hizo et otorgó el mariscal Pero Pardo de Çela en la çibdad de Villamayor a primero día del mes de otubre de myll et quatroçientos et ochenta et tres años, se incluía una cláusula en la que dejó y desembargó las terrarías et benefiçios que llebaba fasta estonzes al dicho obispo de Mondoñedo et a los clérigos en que estavan puestas, et a los que a ellas tenyan derecho, et mandó a sus herederos que no ge los ynpidiesen ny demandasen et les pidió perdón por lo pasado que abía llebado ${ }^{9}$. Consta, por lo demás, que en octubre de 1506 el alcalde mayor de Mondoñedo, Vasco López de Moscoso, decretó un mandamiento de secuestro y embargo de estas terrerías, si bien no parece que esto se ejecutara formalmente hasta el 15 de abril de 1510, según el correspondiente mandato expreso dictado por el juez y provisor de Mondoñedo ${ }^{10}$. Para entonces, el proceso ya estaba en marcha en la Real Audiencia de Galicia, pues el 25 de enero de ese mismo año doña Mayor de Vaamonde había otorgado poder a varios procuradores de causas ante la Avdiencia del sennor governador ${ }^{11}$.

Como fácilmente se comprende, el testamento y codicilo del mariscal Pardo de Cela no fue el único instrumento que se presentó en este largo pleito, que en última instancia se remataría en la Audiencia de Valladolid en el año 1542. Pero de lo dicho más arriba sí se deduce muy bien, sin entrar ahora en los detalles procesales, que el inicio del mismo se justificó efectivamente en la cláusula mencionada y en la consecuente pretensión del obispo de Mondoñedo de recuperar para su iglesia las dichas terrerías y hacer cumplir a los herederos del Mariscal lo que

\footnotetext{
8 Esta doña Mayor de Vaamonde, nieta del mariscal Pardo de Cela y renombrada a veces también como de Bolaño, era una de los siete vástagos — cuatro hembras y tres varones— de doña Beatriz de Castro y de Pedro de Bolaño, señor de Torés. De ellos heredó, entre otros bienes, el puerto y coto de Burela.

9 ARCHV, Sección de Reales Ejecutorias, Leg. 565-1, fols 3v y 4r. y Pleitos Civiles. Escribanía de Alonso Rodríguez $(F)$. Caja 2595-1, fol. 658. Por entonces, la diócesis de Mondoñedo estaba regida por don Pedro de Munébrega (1498-1505); sus sucesores hasta la conclusión del pleito fueron los siguientes: don Diego de Muros III (1505-1512), don Diego Pérez de Villamuriel (1513-1520), don Juan de Loaysa (1524), don Jerónimo Suárez Maldonado (1526-1532), don Pedro Pacheco (15321537) y fray Antonio de Guevara (1538-1545).

${ }^{10}$ Fols. 656 y 467.

${ }^{11}$ Fols. 635-638.
} 
en su testamento se contenía. El propio Obispo lo proclamó formalmente al declararse presto de faser justicia e, en faziéndola, dixo que atento como el complimiento del testamento o la mayor parte de él consistía en pagar debdas et cosas agenas que el dicho Mariscal tenía ocupadas et mandaba restituyr et descargar su conçiençia, que él por servicio de Dios et remedio del ánima del dicho defunto et por lo que debía a su conçiençia et ofiçio que desde agora les proybía et ynterdezía el uso et administaçión de los dichos bienes ${ }^{12}$. Por todo ello, aunque las dos partes litigantes presentaron también otros documentos probatorios, lo más sustancial del proceso que se siguió ante los alcaldes mayores del reino de Galicia giró en torno a la fidelidad de los traslados notariales del testamento que por una y otra parte se aportaron y, más específicamente, respecto a la mencionada cláusula que sólo figuraba en el traslado presentado por el Obispo. Todo ello fue debatido con el auxilio de las consabidas probanzas y la deposición de testigos.

En un resumen del proceso, previo a su traslado a Valladolid, se hace constar que el 16 de agosto de 1510 los alcaldes mayores del reino de Galicia dictaron ya su primera sentencia, favorable en todo - aunque sin dilucidar la cuestión de propiedad - a la demanda presentada por Bernaldino de Castellanos y doña Mayor de Vaamonde:

Todo lo qual visto por los dichos alcaldes mayores dieron sentençia, en que allaron que los mandamientos dados por los dichos provisores del obispado de Mondoñedo heran ningunos et mandaron que por virtud dellos non se fiziese ni ynobase cosa alguna, salvo que estubiese todo en el punto y estado en que estaba antes y al tiempo que los dichos mandamientos fuesen dados et sy sobre la posesyón et propiedad algunas de las partes alguna cosa quisiere desir et alegar lo prosygan et aleguen ante quien et quando vieren que les cumple. Sin costas ${ }^{13}$.

Apenas unos pocos días después, el 24 de agosto de 1510, la parte de Bernaldino de Castellanos y doña Mayor reclamó que les fuesen restituydas las cosas que les avían sido llevadas con la dicha perturbación, suplicando ser amparados en la posesión de las dichas terrerías y que les tornasen quatro bueyes et veinte çelemines de pan que con la perturbación les avían llevado, que estimaban cinco mil maravedies et que hasta tanto no se conosçiese de la propiedad... Pero por entonces el proceso estaba todavía muy lejos de concluir, pues el procurador del obispo de Mondoñedo ya se había anticipado a presentar una petiçión de suplica-

\footnotetext{
$\overline{12}$ Fols. 693-697.

13 Fol. 469.
} 
ción, solicitando en la misma la revocación de la anterior sentencia. Sin embargo, el parecer de los alcaldes mayores no cambió y apenas unos meses más tarde, el 28 de marzo de 1511, la anterior sentencia fue ratificada en grado de revista:

Visto el dicho proçeso por los dichos alcaldes mayores dieron sentençia, en que confirmaron en grado de rebista a la sentençia que por ellos avía sydo dada et atento lo nuevamente alegado et probado que devían amparar et defender y ampararon y defendieron a los dichos Bernaldino de Castellanos et doña Mayor Mayor, su muger, en la posesyón bel casy de las terrerías de Salgadelos et de San Romao et Regueyra de Ferrol y Çerbo et que mandaban al dicho Obispo que agora ni de aquí adelante non le perturbasen en ella et le restituyesen los frutos que le avían llebado et lutuosas dentro de quinze días, la tasaçión de lo qual reserbaron en sí et reserbaron el derecho de la propiedad al dicho Obispo para que lo pudiese pedir et demandar quando y ante quien viere que le cumple contra los dichos Bernaldino de Castellanos et doña Mayor, su muger, et non fizieron condenaçión de las $\operatorname{costas}^{14}$.

La nueva sentencia fue apelada también por la parte del prelado mindoniense, don Diego de Muros, cuyo procurador — hablando con la reverencia et acatamiento que devo - no dudó en reputarla como muy injusta et agraviada por todas las cabsas et razones de nulidad et agravios que del tenor de la dicha sentençia junto a lo procesado se pueden et deven coligir ${ }^{15}$. Consecuentemente, el pleito prosiguió a partir de entonces en la Real Audiencia de Valladolid, donde fue presentado el 11 de noviembre de 1511, y poco más de dos años después, el martes 6 de diciembre de 1513, se dictó una nueva sentencia, ahora ya favorable a las pretensiones del obispo mindoniense, que lo era entonces don Diego Pérez de Villamuriel:

En el pleito que es entre don Diego Pérez de Villamuriel, obispo de Mondoñedo, et su procurador en su nombre, de la una parte, et Bernaldino de Castellanos et doña Mayor de Bahamonde, su muger, bisinos de la villa de Bibero, et su procurador en su nombre, de la otra, fallamos que los alcaldes mayores del reyno de Galisia

\footnotetext{
${ }^{14}$ Fols. 470-471.

15 Fol. 9. Un resumen del proceso iniciado en 1510 ante los alcaldes mayores del reino de Galicia en fols. 467-471; las alegaciones presentadas en la Real Audiencia de Valladolid por el bachiller Francisco de Madrigal, en 2 de diciembre de 1511 y 25 de agosto de 1513, en fols. 33-34 y 55-56.
} 
que deste pleito conosçieron que en la sentençia definitiva que en él dieron et pronunçiaron de que por parte de don Diego de $\mathrm{Mu}$ ros, obispo que fue de Mondoñedo, fue apelado que juzgaron et pronunçiaron mal et que la parte del dicho obispo apeló bien, por ende que devemos revocar et revocamos su juysio et sentençia de los dichos alcaldes mayores et hasiendo et librando en este dicho pleito et negoçio lo que de justiçia deve ser hecho, que devemos asolver et asolvemos al dicho obispo de Mondoñedo de lo contra él pedido et demandado por parte de los dichos Bernaldino de Castellanos et su muger sobre la posesión de las terrerías de Salgadelos et San Romao et Regueira de Ferrol et Çervo, et damosle por libre et quito de ello et ponémosles perpetuo silençio a los dichos Bernaldino de Castellanos et su muger para que non ynquieten más sobre ello al sicho obispo. Et no hazemos condenaçión de costas contra ninguna de las dichas partes et por esta nuestra sentençia definitiva juzgado lo pronunçiamos et mandamos ${ }^{16}$.

El procurador de la parte de Bernaldino de Castellanos y de doña Mayor de Vaamonde presentó a su vez una nueva apelación, en la cual solicitó que se les mandara defender y amparar a los dichos mis partes en la dicha su posesión en que ellos et sus predeçesores estuvieron, para lo qual y en lo necesario vuestro real ofiçio ymploro et ofréscome a probar lo alegado et no probado et lo nuevamente alegado por aquella vía et forma que mejor de derecho lugar aya ${ }^{17}$. Consta que esta apelación se tramitó en Valladolid el 14 de febrero de 1514 y que las probanzas correspondientes dieron comienzo tan sólo una semana más tarde; a partir de julio de 1516, las mismas se centraron en el examen de las dos escrituras más antiguas que el 2 de marzo de ese año habían sido presentadas por la parte de Bernaldino de Castellanos — datadas en $1380^{18}$ y $1401^{19}$, pero la

\footnotetext{
${ }^{16}$ Fols. 67 y $253-254$.

17 Fols. 69-76.

${ }^{18}$ Escritura de trueque y cambio de diversos bienes, otorgada entre don Pedro Tiña de Aguiar y don Lope, obispo de Mondoñedo, en 13 de marzo de 1380. Deberá advertirse que las dudas respecto a este documento no se limitan sólo a la data, en la que no se incluye la era hispánica (ésta se suprimió en la cortes de Segovia de 1383, no antes, y el cambio sólo comenzó a ser efectivo a partir del 25 de diciembre del año siguiente), sino en la identidad del prelado otorgante: en aquel entonces, la diócesis mindoniense estaba regida todavía por don Francisco Eans, mientras que el dicho don Lope — o don Lope de Mendoza, con quien cabe identificarlo — la rigió exactamente entre los años 1393 y 1399. Véase, E. CAL PARdo, Episcopologio mindoniense..., págs. 174-189. El traslado del documento en fols. 539-543.

19 Sentencia dictada el 25 de agosto de 1401 a favor de doña Teresa Rodríguez de Aguiar, mujer de Rodrigo Alonso de Saavedra, en el pleito sostenido con don Álvaro de Isorna, obispo de Mondoñedo, sobre la posesión de diversas terrerías y cotos. El traslado en fols. 544-550.
} 
primera no con la era hispánica todavía acostumbrada en aquella fecha- y cuya falsedad se había apresurado a denunciar la parte del obispo de Mondoñedo ${ }^{20}$.

El expediente conservado, cosido si el orden debido pero aparentemente completo, no ofrece información alguna de lo acontecido entre noviembre de 1516 y julio de 1529 , sin que pueda aventurarse si hubo una renuncia temporal al proceso o sólo una simple inacción de las partes ${ }^{21}$. Lo que sí consta, en cambio, es que por estas últimas fechas se produjo el fallecimiento del procurador de la parte de Bernaldino de Castellanos y de su mujer, doña Mayor de Vaamonde, a los cuales se solicita el 8 de octubre de 1529 la designación de uno nuevo, cosa que no pudo ser cumplimentada a su vez por el fallecimiento de estos últimos, también por aquellos mismos meses. De cualquier forma, a lo menos por lo que aparece reflejado en el propio expediente, la causa no prosiguió hasta el 30 de agosto de 1541, cuando habrían decidido proseguirla los dos hijos de los fallecidos, Pedro Pardo de Aguiar y doña Ana Rodríguez de Aguiar ${ }^{22}$; de ahí, la real provisión del 9 septiembre de 1541, expedida a solicitud del nuevo obispo de Mondoñedo, fray Antonio de Guevara, para que se retomase el pleito y se dictara sentencia contra los mencionados sucesores de Bernaldino de Castellanos y de su mujer, doña Mayor de Vaamonde ${ }^{23}$.

A partir de aquel momento el debate judicial entra ya en su recta final. De esta manera, las declaraciones de las partes y las probanzas sobre la denunciada falsedad de los dos documentos ya dichos se suceden ahora con rapidez, añadiéndose al proceso los traslados de varias escrituras antiguas del archivo y tumbos de Mondoñedo, hechos a instancia del Obispo por el escribano Gonzalo Fuciños, en mayo de $1542^{24}$. La sentencia en grado de revista, favorable a este último, fue finalmente elevada a definitiva el 3 de octubre de 1542:

\section{En el pleito que es entre el Reberendo Yn Cristo Padre Don} Antonio de Guevara, obispo de Mondoñedo, y Juan de Astorga, su procurador, de la una parte, y Pero Pardo de Aguiar, veçino de la cibdad de Mondoñedo, hijo y heredero de Bernaldino de Castellanos y de doña Mayor de Baamonde, su muger, ya defuntos, y Francisco de Betanços, su procurador, y Ana Rodríguez de Aguiar, hermana del dicho Pero Pardo de Aguiar, en su avsençia et rebeldía de la otra, fallamos que la sentençia difinitiva en este dicho pleito dada et pronunçiada por algunos de los oydores desta Real

\footnotetext{
${ }^{20}$ Fols. 484 y 161.

${ }^{21}$ Fols. 188 y 190.

${ }^{22}$ Fols. 194-196.

${ }^{23}$ Fol. 198.

${ }^{24}$ Fols. 237 y $288-324$.
} 
Avdiençia de Sus Magestades, de que por parte de los dichos Bernaldino de Castellanos y doña Mayor, su muger, y por parte de don Diego Pérez Villamuriel, obispo que fue de Mondoñedo, fue suplicado, fue y es buena, justa y derechamente dada et pronunçiada et sin embargo de las razones a manera de agrabios contra ella dichas et alegadas la debemos confirmar et confirmamos en grado de revista, con que debemos amparar y amparamos al dicho don Antonio de Guevara, obispo de Mondoñedo, en la posesión de las terrerías sobre que a sido y es este dicho pleyto y condenamos a los dichos Pero Pardo de Aguiar y Ana Rodriguez de Aguiar, su hermana, a que le dexen libre y desembargada la dicha posesión de las dichas terrerías con todo lo a ellas anexo y pertenesçiente y a que no le ynquieten ni molesten en la dicha su posesión so pena de çien mill maravedies para la Cámara y Fisco de Sus Magestades por cada vez que lo contrario fizieren y condenámosles ansimismo a que le buelban y restituyan todas las lutuosas et otros qualesquier frutos que ellos y los dichos sus padres ovieren llevado de las dichas terrerías desde el día de la contestaçión deste pleito et llevaren fasta la real restituçión y no hazemos condenaçión de costas et por esta nuestra sentençia ansí lo pronunçiamos y mandamos ${ }^{25}$.

El desarrollo del proceso, cuyos hitos quedan recogidos, y la disparidad misma de las respectivas sentencias dictadas en Santiago y Valladolid ponen de relieve, por lo que aquí importa destacar, que el debate en torno a la propiedad y frutos de las consabidas terrerías de Sargadelos, San Romao de Vilaestrofe, Regueyra de Ferrol y Cervo, no se sustanció a partir únicamente del debate generado en torno al testamento del mariscal Pardo de Cela. En realidad, a la vista del expediente completo y de las diferentes pruebas aportadas por las partes, lo que cabe entender es que este documento sólo resultó determinante en el caso de las dos primeras sentencias, dictadas al influjo de las sospechas que suscitaba la ya mencionada cláusula incluida en el traslado presentado por la parte del obispo de Mondoñedo. Los testigos de la parte contraria, a su vez, corroboraron en sus declaraciones las dudas que circulaban respecto a la honradez del escribano Pedro López de Sahagún, responsable de aquel traslado y de otras escrituras también determinantes para el proceso, todas las cuales fueron reputadas como falsas et falsamente fabricadas por Bernaldino de Castellanos ${ }^{26}$. Entre estas úl-

\footnotetext{
25 Fols. 252 y $255-256$.

${ }^{26}$ Fols. 347-360, 446-449 y 707: Bernardino de Castellanos por mí et en nombre de doña Mayor de Vaamonde, mi mujer, digo que en el pleito que yo trato con el dicho obispo de Mondoñedo et sus provisores et los otros sus consortes, por su parte ha presentado un testamento del mariscal
} 
timas figuraba cierta declaración jurada del mariscal Pardo de Cela, otorgada en 14 de junio de 1481, por la cual éste habría reconocido que llevaba las citadas terrerías por los días de su vida y no más en préstamo del obispo don Fadrique de Guzmán, según antes las había llevado también su padre, comprometiéndose de seguido en que al tiempo de mi muerte que queden libres et desembargadas a la mesa obispal ${ }^{27}$. La falsedad de todos estos documentos — principalmente la cláusula testamentaria y la antedicha declaración-quedó al fin definitivamente probada tras la confesión y reconocimiento del delito por parte del propio escribano, al cual se había mandado comparecer en Santiago el 27 de agosto de 1510:

Et yo, el dicho Pero López de Saagund, en respondiendo a lo contenido de esta otra parte en razón de la redarguyçión del testamento del Mariscal et çédula firmada del dicho mariscal, digo et respondo que sy alguna cosa fize que lo fize por importunidad et mandamiento et premia del obispo don Pedro de Muniebrega et Antón Gutiérrez, su maestresala, y el bachiller Rosales, su alcalde mayor, que me tovieron et metieron en una cámara et me fizieron faser lo sobredicho por fuerça et contra mi voluntad, amenazando que lo fiziese $e^{28}$.

Pero Pardo, en que dize que el dicho Mariscal desembargó las dichas terrerías sobre que es este pleito et porque, en quanto aquéllo, el dicho testamento hes falso et falsamente fabricado, según paresçe por este otro testamento original et verdadero que aquí presento, et por tal lo redarguyo çebilmente, a vuestra merçed pido et suplico mande fazer et faga según que pedido tengo en el artícolo posesorio dando por ningunos qualesquier mandamientos dados por el dicho Obispo et por los dichos sus provisores, defendiéndome et amparándome en la dicha mi posesión, et juro a Dios que lo suso dicho no alego maliciosamente et que agora vino a mi noticia la dicha falsedad et pido complimiento de justicia et las costas et concluyo en la misma execuçión de falsedad alego contra el conosçemiento que presenta del dicho mariscal Pero Pardo.

27 Fols. 692.

${ }^{28}$ Fols. 1159-1160 y 514-515; véanse también las probanzas en fols. 363-366. Cabrá recordar, por lo demás, que el dicho Pedro López de Sahagún hizo otra confesión ante numerosos testigos y, en particular, el propio Bernaldino de Castellanos y el licenciado García de Talavera, corregidor de Vivero: En el monasterio de San Francisco de Vivero, el 28 de noviembre de 1510, estando presente el abad, frey Alonso, el dicho Pedro de Saagund estando en la cama, enfermo, dixo a altas vozes que por razón que él hera cristiano et en este mundo fisiera muchos pecados et usara mal de su ofiçio, et agora estaba constetuydo en artícolo de la muerte et non tenía por dónde satisfacer aquellas personas a quien avía herrado, pero que como católico cristiano se arrepentía et quería debulgar su carne en aqueste mundo por razón de la ver mérito en aquel para su ánima, por ende dixo que pedía et pedió a mí el dicho escribano que le diese por fe et testimonio signado como el públicamente confesaba que avia fecho un conosçemento a pedimento de Lope Alvares, vesyno que fue desta villa de Vibero, el qual sonava que el señor mariscal Pero Pardo se obligaba de pagar cien doblas al dicho Lopo Alvares, no aviendo pasado ansy, nin lo conosçiendo el dicho Mariscal, defunto, sino como por enganno que le fisyera el dicho Lopo Alvares desyendo que serían las dichas çien doblas para los herederos del dicho señor mariscal o lo que por virtud del dicho conosçemento 
Aunque huelga insistir en la importancia de esta rotunda confesión, no está de más recordar aquí que este Pedro López de Sahagún, escribano, decía haber sido secretario del señor Mariscal, con quien había vivido muchos años — cuarenta según su cuenta-, y había depuesto además como testigo de la parte del obispo mindoniense, constando que en su declaración había dado por supuesta, naturalmente, la validez de la consabida cláusula testamentaria y de los otros documentos de su autoría ${ }^{29}$. Finalmente, en efecto, todas aquellas falsedades se hicieron patentes y, tras la confesión de Pedro López de Sahagún, quedó comprobado el delito y que savía faser la firma del dicho señor Mariscal et la fasía cada et quando quería ${ }^{30}$. De ahí, por consiguiente, el signo de las dos primeras sentencias dictadas en Santiago e, incluso, la orden de prisión que según parece se dictó contra el escribano falsario, que buscó refugio en una celda del monasterio de San Francisco de Vivero, donde se quemó y murió dentro de una celda, como recuerdan muy bien diversos testigos.

\section{COMENTARIO DEL DOCUMENTO}

Como ya he anticipado más arriba, el mariscal Pardo de Cela otorgó su testamento y codicilo los días 1 y 3 de octubre de 1483, estando en Mondoñedo, preso dentro de una cámara en casa del canónigo Fernán Balea. De ambos instrumentos dio fe el escribano Diego Pérez, notario público do sennor obispo de Mondonedo en a çibdade de Villamayor et en todas las otras villas et lugares do seu obispado, cuya actividad documenta Enrique Cal Pardo a partir del año $1456^{31}$. Lamentablemente nada se sabe del paradero o destino de su registro no-

podiese alcançar et que él, pensando que el dicho Lope Alvares lo faría ansy et por salvar algunos byenes para los dichos herederos, diera por fe lo susodicho, non seyendo nin pasando ansy por ende que agora lo confesaba públicamente et mandaba demandar perdón a los herederos del dicho señor mariscal a cada uno en su persona et se la demandava en absençia et rogaba a mí el presente escribano se lo diese por testimonio et a los presentes que fuesen dello testigos... Fol. 1162.

${ }^{29}$ Fols. 906-910.

${ }^{30}$ Fols. 1163-1164. Los testigos lo corroboran con diversos testimonios. Uno de ellos, por ejemplo, recuerda que le oyó decir y confesar al dicho Pedro López que él falseaba la firma del Mariscal quando quería, et aún la de doña Beatriz también, et questo se lo oyó confesar hartas veçes en esta villa de Bivero... Otro, por su parte, recuerda que en cierta ocasión el dicho Pedro López de Sahagún tomó una escritura firmada del Mariscal et por su firma hizo otra tal en otra escritura... et que por esto sabe que el dicho Pedro López contrahizo la firma del Mariscal tan propia como la misma del Mariscal quando el dicho Pedro López quería, et que el dicho Mariscal hera muerto... Fol. 363.

${ }^{31}$ Este Diego Pérez, notario, se documenta en diversas ocasiones a partir de 1456, cuanto menos, y el texto de validación que figura en el testamento del Mariscal se repite a su vez sin gran variedad formal en diversos instrumentos. En 1457, por ejemplo: Et eu Diego Peres, notario público dado do sennor obispo de Mondoñedo... Véase, Enrique Cal Pardo, Colección Diplomática medieval do Arquivo da Catedral de Mondoñedo, Santiago de Compostela, Consello da Cultura Galega, 1999, 
tarial, en el que estaría estampada la firma del Mariscal, y otro tanto cabe decir respecto al documento original, o primera copia, que Bernaldino de Castellanos y doña Mayor de Vaamonde presentaron en el proceso de referencia y que mantuvieron en su poder cuanto menos entre los años 1510 y 1514, sin que haya constancia de que durante este tiempo saliera de Galicia:

Et en las espaldas del dicho testamento está un escrito et asinado lo que sygue: fue presentado en Santyago, a dos días del mes de agosto de mill et quinientos et diez annos en avdiençia. En la çibdad de Santyago, a nueve días del mes de setyenbre de mill et quinientos et diez annos. Ante mí, Juan Nieto, et firmado de una firma. Testamento oreginal de Pedro Pardo, el mariscal, presentado por Vernaldino de Castellanos ${ }^{32}$.

Se sabe, por otra parte, que el documento estaba escrito en papel, no en pergamino, como se hace constar con claridad algunos años más tarde, cuando Bernaldino de Castellanos lo presentó en Vivero, a fin de que se hiciera un nuevo traslado del mismo, señalándose que presentava et presentó una escritura de testamento et codesilo del mariscal Pedro Pardo de Çela sygnado de escrivano público (...) todo escrito en papel (...) de berbo ad verbo es este que se sigue... Nada puede asegurarse, por lo demás, respecto a la lengua con la que fue redactado el original, aunque probablemente predominarían los giros y expresiones propios de la lengua gallega coloquial de la época, pues es fácil suponer que tanto el mencionado escribano mindoniense, Diego Pérez, como su criado y amanuense, Juan Tomás, no debían ser personas muy avezadas en la lengua castellana. Sin embargo, estas apreciaciones, pertinentes al caso pero poco consistentes por sí mismas, no pueden ser confirmadas a través de los otros documentos presentes en el pleito, pues los redactados originalmente en lengua gallega aparecen trasladados de igual manera, aunque con las inevitables e involuntarias deturpaciones acostumbradas; exactamente igual ocurre con los que estaban redactados originalmente en castellano, caso de los emitidos por el controvertido notario Pedro López de Sahagún, que se decía secretario del señor Mariscal y cuyas escrituras conocidas están todas redactadas en esta última lengua, cosa no extraña, pues parece que era natural de la villa de su nombre.

doc. 177, pág. 325 y Catálogo de los documentos medievales, escritos en pergamino, del Archivo de la Catedral de Mondoñedo, Lugo, Diputación Provincial, 1990, docs. 1341, 1582, 1598 y 1599. Por las declaraciones de varios testigos se conoce también la personalidad y circunstancias del amanuense que lo puso a la letra: un Juan Tomás, criado del dicho Diego Pérez, al cual luego sucedió en el oficio. Referencias en fol. 368.

${ }^{32}$ Apéndice, documento 1. 


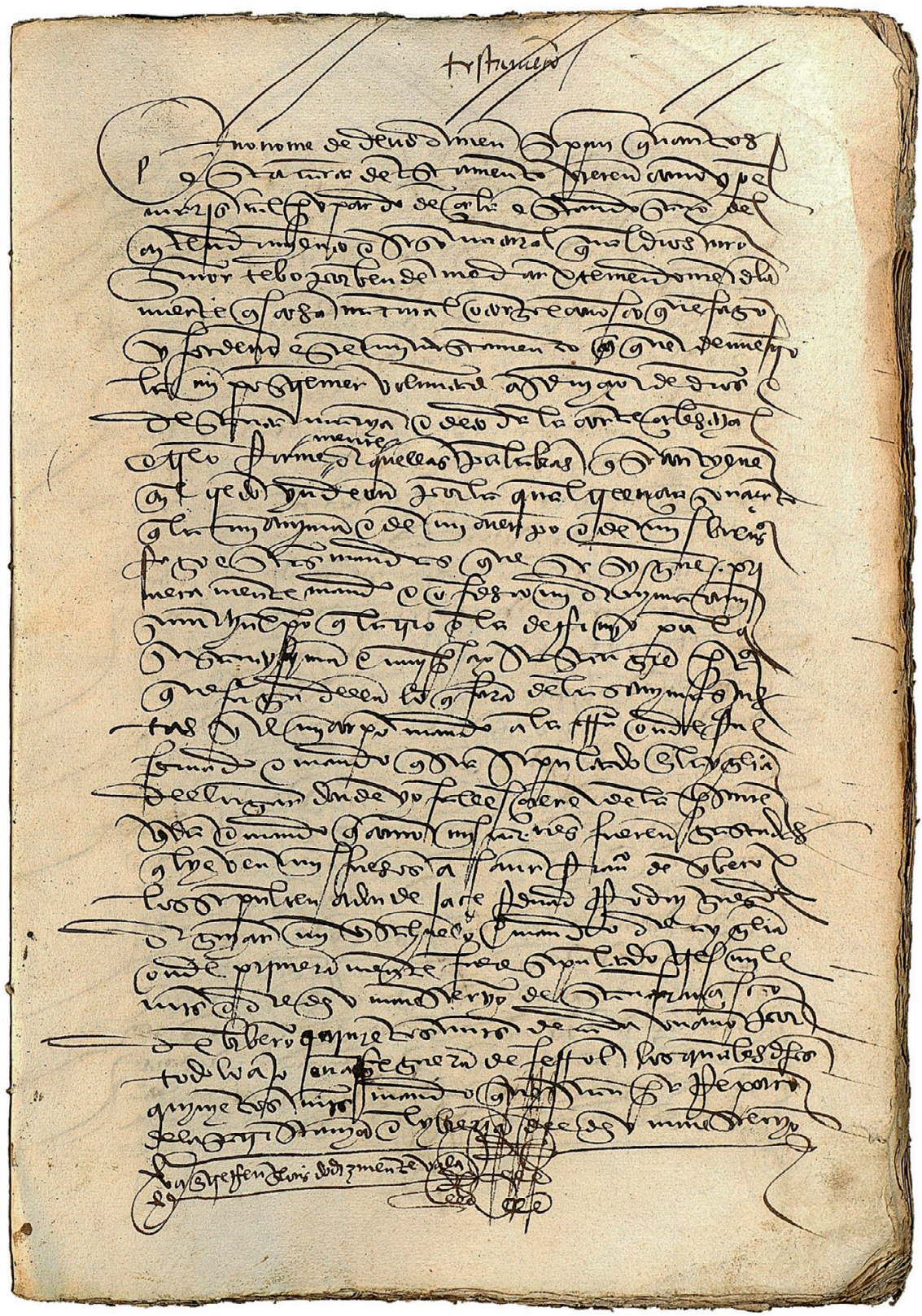

Fig. 1

Testamento del mariscal Pardo de Cela (traslado del original presentado por Bernaldino de Castellanos en la Audiencia de Santiago el 2 de agosto de 1510). ARCHV, Pleitos Civiles, Escribanía de Alonso Rodríguez, caja 2595-1, fol. 499. 
El contenido completo del testamento y codicilo se conserva sólo en los tres mencionados traslados notariales que figuran en el expediente de referencia. El primero que se aporta al proceso es un traslado hecho el 27 de junio de 1510 a partir de otro sacado - y amañado — por Pedro López de Sahagún, el cual había sido presentado en Santiago el 18 de junio anterior, estando en la Audiencia los alcaldes mayores, por el procurador Juan de Villanueva en nombre del Obispo de Mondoñedo; lo sacó Alvar Núñez, secretario, con presencia de la parte contraria, siendo también testigos del cotejo Bartolomé García, escribano, Fernán de Sanjuliao, Martín Voon, Palomino, y otros ${ }^{33}$. El segundo traslado notarial, a su vez, se sacó también en la Audiencia de Santiago ante el gobernador y los alcaldes mayores, el 2 de agosto de 1510, y a partir del documento original —o primera copia - que había presentado Bernaldino de Castellanos y su mujer doña Mayor de Vaamonde ${ }^{34}$. El tercero, por último, es otro traslado notarial hecho en Vivero el 21 de febrero de 1514 por Alonso de Villalobos, escribano y receptor de la reina en la villa de Vivero, a partir otra vez del ya mencionado documento original que poseían Bernaldino de Castellanos y su mujer ${ }^{35}$. De estos tres traslados, el más cercano al original y el mejor transcrito o con mayor rigor trasladado es, pese a algunas de sus limitaciones, el segundo de los mencionados; es decir, el que se sacó a la vista del original presentado por Bernaldino de Castellanos y doña Mayor de Vaamonde, su mujer, el 2 de agosto de $1510^{36}$; este parecer es el mismo que sostuvieron los alcaldes mayores de la Audiencia de Galicia y que determinó, según ha quedado resaltado, el signo de las sentencias dictadas en 1510 y 1511. Por el contrario, el primero de los mencionados - el presentado por el Obispo de Mondoñedo- es notoriamente el más alejado e incorpora además dos añadidos significativos en sendas cláusulas, los cuales benefician el interés del obispo mindoniense y del propio escribano que lo trasladó y son fruto, naturalmente, de la falsificación que este último confesó; se comprende,

\footnotetext{
${ }^{33}$ Fols. 706-707.

${ }^{34}$ Fols. 709-726 y 707: Bernaldino de Castellanos y doña Mayor de Vaamonde presentaron una petición para demostrar la falsedad del testamento presentado por el Obispo, que hes falso et falsamente fabricado et incorporar según paresçe por este otro testamento original et verdadero que aquí presentó, et por tal lo redarguyó çebilmente. Tras aceptar la petición de Bernaldino de Castellanos, los alcaldes mayores determinaron el 2 de agosto de 1510 que se incorporara una escriptura synada de Diego Peres, que es un testamento del mariscal Pero Pardo... y los dichos señores mandaron dar treslado, et que dentro de ocho días traygan el testamento original que se presentó de la parte del dicho obispo para que lo bean et provean, en el dicho caso, aquello que sean justiçia. Presente Villanueba, procurador de la otra parte. En tres del dicho mes et año se notificó a Palomino en su persona que trayga la dicha escriptura original como los dichos señores lo mandan. De la qual dicha escriptura su tenor es este que se sigue... Sin embargo, el Obispo nunca presentó el documento original que se le solicitaba.

${ }^{35}$ Fols. 493-494, 498 y 499-521.

${ }^{36}$ Ver Apéndice: Documento 1.
} 
sólo por ello, que la parte del prelado no llegara a presentar nunca — pese a los requerimientos que se le hicieron - el original que decía tener, sino sólo el amañado traslado del original, que es justamente el único que nos ha llegado como traslado de un traslado anterior ${ }^{37}$.

Por consiguiente, con independencia de los añadidos apócrifos que quedan señalados y de los otros diversos errores de orden menor — sin intención o sin sustancia significante-, los mencionados traslados del testamento y codicilo deben ser considerados testimonio fiel de las últimas voluntades — la última palabra como las han llamado_ - del mariscal Pardo de Cela. Esta obviedad, sólo aparente, constituye una invitación inexcusable para considerar cuáles fueron el momento y las circunstancias en que se produjo el otorgamiento de ambos documentos.

En mi opinión, la fecha debe ser relacionada directamente con la condena y ejecución de Pardo de Cela, la cual en todo caso no pudo tener lugar el consabido 17 de diciembre que transmite la tradición, sino en un momento inmediato o muy próximo al otorgamiento del codicilo; esto es, el mismo 3 de octubre o muy poco después, pues así se desprende del testimonio de varios de los testigos que deponen en el proceso, quienes aseguran además que estuvieron presentes en aquellos acontecimientos. La declaración de uno de ellos, por de pronto, parece dar a entender esa proximidad entre ambos momentos, aunque de manera muy imprecisa pues manifiesta que vio degollar al dicho mariscal Pero Pardo et que, antes que lo degollasen en la çibdad de Mondoñedo, hiziera su testamento en casa de Fernán Balea, canónigo, dentro de una camara adonde le avien preso $^{38}$... Otro testigo, por su parte, resulta mucho más esplícito al declarar que el otorgamiento del mencionado codicilo fue la víspera del día que lo degolla-

\footnotetext{
37 Ver Apéndice: Documento 2.

${ }^{38}$ Fol. 369. La declaración completa es como sigue: Dixo que puede aver el tiempo de veynte et nueve o treybta años poco más o menos tiempo que este testigo vio degollar al dicho mariscal Pero Pardo et que antes que lo degollasen en la cibdad de Mondoñedo hiziera su testamento en casa de Fernán Balea, canónigo, dentro de una cámara adonde le avien preso et viera estar por testigos presentes al prior de Sant Martino et al provisor Álvaro García de Luarca et a otros que no se acuerda. Fuele mostrado el dicho testamento original de que en la pregunta se haze mención et visto dixo que el dicho testamento sabe que pasara et pasó ante el dicho Diego Peres, notario, porque a la sazón que dicho tiene que viera a los susodichos en la dicha cámara ante el dicho Mariscal, a donde estaba preso, le viera allí también al dicho Diego Peres, notario, et no vio a otro escribano ninguno sino a el que este testigo conosçiese ni viese et que la letra del a todo su creer es fecha de mano del dicho Juan Tomás, defunto, que fue su criado, porque le conosçió et vio escrevir hartas vezes et fue después notario et ombre de pro et escribano de buena fama et que ansimismo conosçió al dicho Diego Peres, notario, et le conosçió por ombre de buena fama et cree que la letra de la suscriçión et la firma et sygno et letra de la firma es del dicho Diego Peres, et que lo cree porque ha visto otras escrituras signadas de su signo por dos o tres vezes en Mondoñedo et por eso le parece las otras y esta ser de una mano fechas et toda una et que el dicho testamento le tiene este testigo
} 
ron $^{39}$... Pero el testimonio más creible y seguro en este y otros detalles parece ser el de Ares Pérez de Villadonga, prior de San Martín de Mondoñedo y canónigo de Mondoñedo, pues consta que vivió muy de cerca aquellos momentos finales del Mariscal, con quien reconoció además que tuvo mucho trato et amistad et conversación $^{40}$. Su declaración respecto a todo esto es como sigue:

Dixo que lo que de la dicha pregunta sabe es que puede aver los dichos veynte et siete años que es en la dicha pregunta que morió el dicho Mariscal, porque estaba con él quando estava preso al tiempo que lo degollaron. Et estando así con él vido que el dicho Pero Pardo, mariscal, fizo un codiçillo el día que lo degollaron et rogó a este testigo que lo escribiese, en que otras cosas por el mandava dixo que por una clavsula del dicho codiçillo que desembargava las terrerías que llevaba de la Yglesia de Mondoñedo, cuyas ellas heran, et los benefiçios a los clérigos en quien estavan puestos et que el dicho codiçillo fue otorgado por ante un notario que se llamava Diego Pérez, de Mondoñedo, que hera al dicho tiempo escribano de la audiençia del Obispo, por ante quien avía pasado asimismo el testamento del dicho Mariscal ${ }^{41} \ldots$

\footnotetext{
por el mismo original del dicho Mariscal por lo que dicho tiene et porque nunca vio ni oyó desir de otro ningund testamento salvo de este et que esto es lo que sabe.

${ }^{39}$ Fol. 407. La declaración completa de este testigo, Pedro de Louriña, clérigo beneficiado de Santa María de Burela y de 60 años de edad, es en este punto como sigue: que al tiempo que el dicho Pero Pardo estaba preso en esta dicha ciudad de Mondoñedo, víspera del día que lo degollaron, estaba este testigo presente en casa de Fernán Balea, canónigo, donde el dicho Pero Pardo, mariscal, estaba preso, et allí vido que venieron a hablar con él el prior de San Martiño et el bachiller de Luarca, que al dicho tiempo era Provisor, et estando este dicho testigo presente oyó decir cómo el dicho bachiller de Luarca le dixo que desembargase lo suyo libremente a la Iglesia, et el dicho Pero Pardo dixera que desde allí lo desembargaba todo lo que della llevaba. Et después acá que el dicho Mariscal falesció, siempre los vido [a las partes pleiteantes] andar en pleitos et diferencias sobre las dichas terrerías et lutuosas. Et que el dicho codicillo fue otorgado por ante un notario que se llamaba Diego Pérez, de Mondoñedo, que era al dicho tiempo escribano de la abdiençia del Obispo, por ante quien avía pasado asimismo el testamento del dicho Mariscal...

${ }^{40}$ En febrero de 1484 se le documenta como prior y en 1485 como Arias Peres de Billadonga, bachiller en Decretos, administrador perpétuo del monasterio de San Martino de Mondoñedo... Como tal prior y administrador perpétuo le correspondió regir también los monasterios de San Miguel de la Colleira y San Salvador de Pedroso a partir de 1485 y 1493, coincidiendo con sus respectivas anexiones al primero; consta que todavía vivía por el año 1515. Estas y otras diversas noticias en E. Cal Pardo, Colección Diplomática medieval do Arquivo da Catedral de Mondoñedo..., doc. 204, pág. 421, El monasterio de San Miguel de la Isla de la Colleira. Colección Documental, Lugo, [s.n.], 1983, págs. 27, 35 y 37, y El monasterio de San Salvador de Pedroso, en tierras de Trasancos. Colección documental, La Coruña, Diputación Provincial, 1984, págs... 119-120 y 202. ${ }^{41}$ Fol. 406.
} 
No hay duda, por consiguiente, que el momento del otorgamiento coincide con lo que fue el último capítulo en la vida del Mariscal, lo cual no contradice necesariamente lo transmitido por la tradición, al menos en lo que se refiere a los diez días que mediaron entre el apresamiento y la ejecución pública en la plaza mayor de Mondoñedo. Aunque nada puede añadirse con seguridad en relación con estas circunstancias y menos, todavía, con respecto al proceso y condena previos, salvo la sola confirmación de que esos fueron exactamente los procedimientos legales que se siguieron, las declaraciones de los diferentes testigos del pleito de referencia sí aportan algunos detalles valiosos — tal como la prisión dentro de una cámara en las casas de morada del canónigo mindoniense Fernán Balea- que arrojan cierta luz en medio de la oscuridad de aquellos acontecimientos, hasta ahora del todo impenetrables. Resulta extraño, sin embargo, que en el testamento no se incluya ni una sola mención expresa a todo esto, aunque sí hay una huella determinante y muy fácil de advertir. Me refiero, como fácilmente se comprenderá, a la nómina de los testigos que asisten a su otorgamiento y entre los cuales no se reconoce a nadie del entorno familiar y señorial del mariscal Pardo de Cela, como era habitual en este tipo de instrumentos, sino a un pequeño pero significativo número de eclesiásticos, casi todos dignidades y prebendados vinculados a la iglesia mindoniense, y un más reducido pero no menos significativo número de escuderos y criados del rey de origen o naturaleza no gallega, como lo evidencian sus respectivos renombres o apellidos, todos de raigambre netamente castellana:

Testygos que fueron presentes, llamados et rogados: el reberendo sennor Albaro Garçia de Luarca, bachyller en decretos et probisor en la yglesia de Mondonedo, et don frey Fernando de Bolanno, ministro de la probençia de Santyago, et administrador del monesterio de Villanueba, et Fernan Balea, canonigo, et Gonçalvo Yanes et Diego Fernandez de Labrada, canonigos, et Roy Garçia, suchanter, et Martin Vasques, clerigo, et Gil de Baracaldo, et Juan Sanches de Carion, clerigo de la diocesis de Palençia, et Miguel Sanches de Bobadilla, et Galor de Baçan, et Christobal de Mata, et Pero Xaramillo, escuderos et criados del rey, nuestro sennor.

Aunque en el testamento y codicilo del Mariscal no hay, en efecto, las referencias expresas que cabía esperar respecto al momento y las circunstancias que motivaron y rodearon su otorgamiento, esto en modo alguno puede inducir a minimizar el valor de la información que en el mismo se contiene. En términos generales, se trata de un testamento que no se aparta del tono y orden entonces utilizados en este tipo de instrumentos; es decir, un documento mediatizado por 
la costumbre, en el que se entremezclan el texto jurídico y el acto religioso, por el cual el otorgante confiesa su fe, reconoce sus pecados y procura redimirlos ${ }^{42}$. De aquí, en primer término, el llamado preámbulo introductorio, donde el Mariscal hace su declaración de fe en que demuestro la mi postrimera boluntad a serviçio de Dios et de Santa María, et de toda la corte çelestial, et creo firmemente aquellas palabras que se contenen en el Credo yn Deo, por la qual creençia son çierto que la mi ánima será salva ante la faz de mi Sennor Jhesu Chisto, sy ante non, syno al día del muy gran juyzio... Y así, también, la incorporación de las diferentes disposiciones de índole espiritual y religioso, donde se incluyen las mandas pías y los legados caritativos que completan o complementan la cláusula destinada al enterramiento; entre ellas, el Mariscal introduce las que benefician a los monasterios de San Salbador de Villanueba, en Lorenzana, San Martinno de Mondoñedo y al propio de San Françisco de Vibero, además de las referidas al envío a su costa de un romero a Santa María de A Guadelupe, otro a Santa María de Villavade y tres a Santiago d'Espanna, logo como entrar el jubileo, precisando de seguido que sean personas de buena bida, et que den a la iglesia, para la obra, cada romero dozientos maravedís... Y junto a todo esto cabe situar ya, claro está, el mucho más amplio conjunto de las cláusulas que suelen denominarse civiles o propiamente dispositivas, donde el Mariscal parece poner especial cuidado en descargar su conciencia y ordenar todas las cuestiones que afectan a algunos de los bienes y rentas que percibía, con o sin título suficiente; es llamativo en este punto el número de los desembargos, deudas, reparos y compensaciones diversas de carácter patrimonial, pues constituyen casi un tercio del grueso de las mandas, y cuyo tenor permite localizar espacialmente el origen de esta parte de sus recursos. En último lugar figuran ya, por fin, las disposiciones relativas al resto de los bienes, que sólo especifica en casos muy concretos o señalados, designando herederas de los mismos a sus dos hijas legítimas, doña Constanza y doña Beatriz, y como testamentarios o cabeçaleiros a doña Isabel de Castro, su mujer, y a Ruy González de Ribadeneira, su sobrino, a los quales pongo et apodero en todos mis bienes muebeles et rayzes para que sin mandamento de juez nin de alcalde ayan libre et conplidopoder para entraz (sic) et tomar que tantos dellos quantos ellos quisieren et por ven tobieren, et los puedan vender et rematar para que de lo que balieren et por ellos dieren cunplan et paguen todo

\footnotetext{
${ }^{42}$ Philippe ArIÈs, El hombre ante la muerte, Madrid, Taurus, 1983, pág. 161. Una útil visión general del tema en Juan Carlos MARTín CEA, "El modelo testamentario bajomedieval castellano y su reflejo en los diferentes grupos sociales", Edad Media. Revista de Historia, 6 (2003-2004), págs. 103-156.
} 
lo contenido en este testamento se encomienda el cumplimiento de las cláusulas y la liquidación final de los bienes ${ }^{43}$.

De entre todo lo que en el testamento se contiene sólo cabe anticipar aquí la cláusula relativa al enterramiento, pese a que no se trata de un detalle novedoso, pues la misma ya ha sido dada a conocer en diversas ocasiones - la primera creo que en el año 2010 - por Carlos Breijo, quien tuvo la fortuna de localizarla en un pleito conservado en el Archivo del Reino de Galicia ${ }^{44}$. Por la misma, en cualquier caso, el Mariscal dispuso ser sepultado en la yglesia del lugar donde yo falesçiere desta presente vida, aunque ordenando de seguido que como mis carnes fueren gastadas que llieven mis huesos a San Françisco de Vibero, et los sepulten honde jaz Fernán Rodrigues d'Aguiar, mi bisabuelo. De momento no es posible determinar si en algún momento sus herederos llegaron a cumplir esta última voluntad; es posible que así fuera, pero la sola existencia de esta cláusula parece explicar de manera suficiente que en la catedral de Mondoñedo, donde debieron ser depositados sus restos tras el degollamiento, no haya quedado rastro ni noticia alguna de su enterramiento, cuya factura y lugar tuvieron que estar condicionados necesariamente por la provisionalidad dictada en la mencionada disposición. Sí es mucho más probable, en cambio, que se cumplieran las otras obligaciones; esto es, los tres mil maravedíes para la yglesia donde primeramente fuere sepultado y los quinientos anuales para el dicho monesterio vivariense, específicamente destinados al reparo de la sacristanía et libraría del dicho monesterio, incluyendo en este montante la manda pía que obligaba a su comunidad: et que me digan por las fiestas de febrero et de março et de agosto et setienbre de Nuestra Sennora una misa cantada, por mi anima et de mis antepasados, et otra por dia de San Françisco, et que sean çinco en el anno para senpre; et mando que me fagan

\footnotetext{
${ }^{43}$ Este Ruy González de Ribadeneira no debe ser confundido con su primo homónimo, fallecido hacia 1467, que era hermano de Fernán Díaz, Berenguela López y Diego Sánchez, todos hijos de Álvaro González de Ribadeneira y de doña Teresa Fernández, su mujer. El que se menciona en el texto como cabeçaleiro era, en realidad, hermano del célebre mariscal Álvaro González de Ribadeneira y ambos hijos de Diego Sánchez de Ribadeneira, hermano de la mencionada Teresa Fernández, y de doña Teresa Rodríguez de Aguiar, hermana a su vez del mariscal Pardo de Cela y viuda de Alonso López de Saavedra. El personaje, asentado en Vivero, casó con doña María Sarmiento, hija de don García Sarmiento y doña Mencía Sarmiento de Zúñiga, segundos condes de Santa Marta; de ellos quedó sucesión bien conocida: doña María Sarmiento, señora de Celme y Laza, casada con Álvaro de Oca y Deza, y Pedro Sarmiento de Sotomayor, señor de Bentraces, casado don doña Leonor Osorio.

${ }^{44}$ En el mismo consta la reclamación de los franciscanos de Vivero para que los herederos cumplieran lo estipulado en la mencionada cláusula testamentaria, que naturalmente se incluye junto a otras correspondientes al testamento de su hija, doña Beatriz de Castro. Véase, Xosé Carlos BreiJo, "San Francisco de Viveiro e as últimas vontades do Mariscal Pedro Pardo de Cela e da sua filla dona Beatriz de Castro", en El Heraldo de Vivero, 19 de noviembre de 2010 (núm. 3728), págs. 3 y 8.
} 


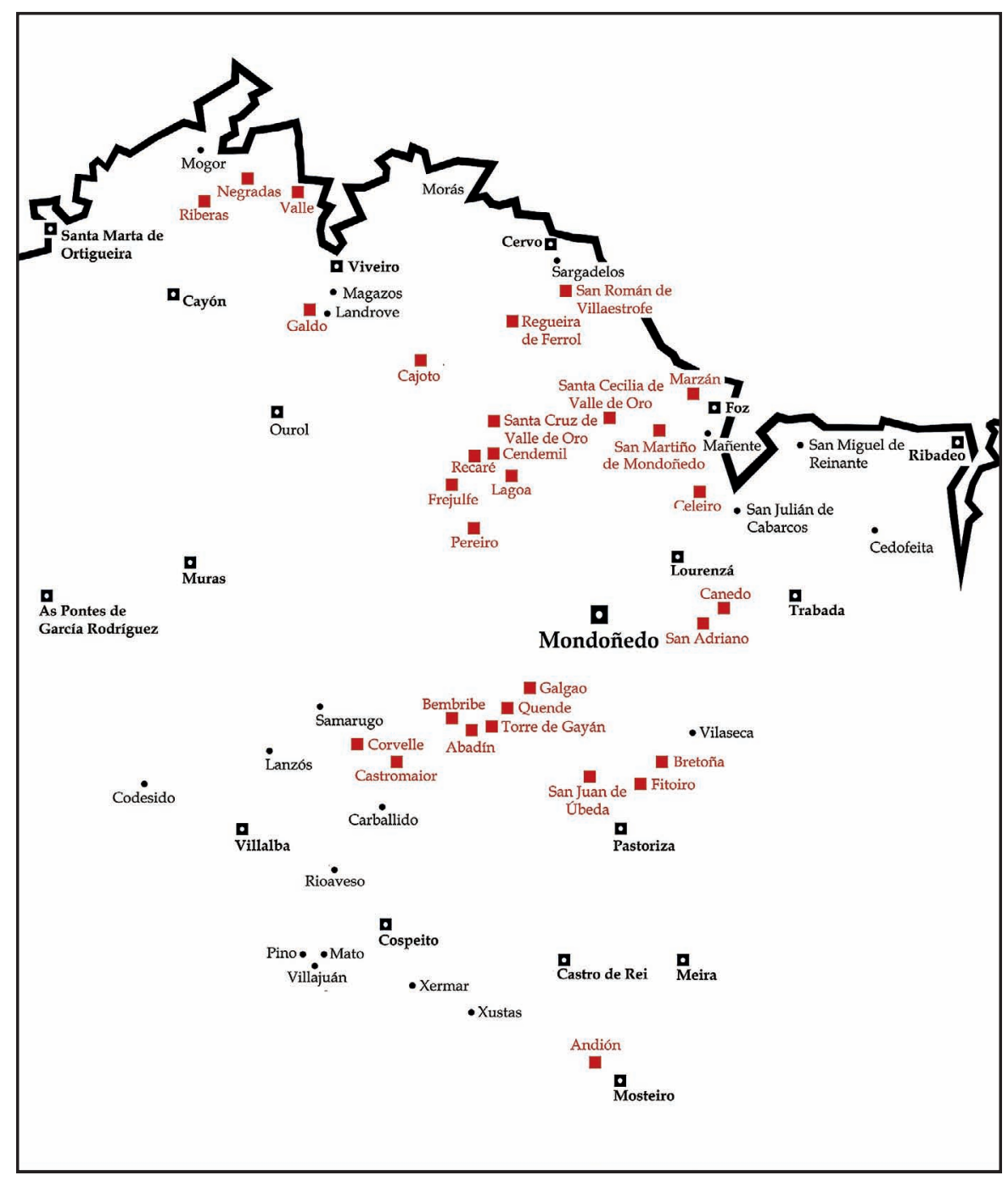

Fig. 2

Localización de los bienes que se mencionan en el testamento del Mariscal.

mis honrras et osequias en el dicho monesterio de San Françisco de Vibero, como pertenesçe a mi honrra et estado.

Nada cabe considerar aquí, por el contrario, en relación con las diferentes referencias vitales que se incluyen en el testamento, ni tan siquiera en el caso de las mucho más numerosas que atañen a un buen número de parientes y allega- 
dos, pues todo ello es asunto que excede al objetivo pretendido y a la inevitable limitación de estas páginas. Se trata, por lo demás, de una información en la mayor parte de los casos ya conocida y contrastada, mientras que en los otros las menciones resultan en exceso escuetas e imprecisas, o sin contexto suficiente, por lo que su valoración no puede ser madurada y completada sin la confluencia con otras fuentes. Pese a lo dicho, creo que no puede dejar de destacarse la singular mención que el Mariscal hace a un hijo de cuya existencia nada se sabía con seguridad:

Yten nonbro por voz en el fuero del coto de Frejulfe a Juan Núnez. Pardo, mi hijo, para que lo aya et llieve con las vozes que tiene después de la muerte de la dicha donna Ysabel, mi muger, porques mi boluntad qu'ella, en su bida, lo llieve, et después de su muerte que lo aya el dicho Juan Nunnez Pardo, mi hijo.

La naturaleza no legítima de este hijo se deduce muy bien de la referencia del propio Mariscal, pues no precisa que sea hijo de doña Isabel de Castro, su mujer, y en todo caso lo aparta de la masa hereditaria y lo situa claramente al margen de la mención que hace poco después a sus dos hijas, doña Constanza y doña Beatriz, cuya legitimidad sí declara de manera expresa, nombrándolas además sus legitimas y universales herederas. Esta circunstancia de origen -incluída la propia bastardía - se refuerzan todavía más en el codicilo, donde el Mariscal ruega y manda a sus herederos por la mi bendiçion et so pena de maldiçion que non ocupen nin tomen el coto de Frejulfe a Juan Nunnez Pardo, mi fijo, porque yo lo fize et nonbré por voz et persona del, et mando que moriendo él menor de hedad, que quede a mis herederos... Poco más puede añadirse en torno a este nuevo personaje, que ahora irrumpe sin sombra de dudas en la vida del mariscal Pardo de Cela y de la misma manera parece que se desvanece después, pues nada posterior consta de él, ni siquiera si llegó o no a hacerse cargo del mencionado legado... No obstante, a pesar de que la tradición se hace eco de su existencia, se me antoja un tanto aventurado aceptar ahora, sin más averiguación, lo que en ella y en algún texto cronístico se ha consagrado; esto es, que aquel hijo — todavía un niño probablemente - corrió el mismo fatídico destino que su padre en la plaza mayor de Mondoñedo ${ }^{45}$.

\footnotetext{
${ }^{45}$ Esto mismo parece dar por sentado Diego de Valera, cuando en su celebrada crónica identifica a los que fueron ejecutados junto a Pardo de Cela: e con él -escribe- a Pedro de Miranda, e a García Rodríguez de Bordel, e a Bartolomé de Bahamonde, e a un fijo del Mariscal, e a otro fijo de Pedro de Miranda, los quales todos por su mandado fueron degollados, los quales eran hombres de estado e linaje. En galardón de lo qual fue ordenado que en las dichas iglesias se ficiese perpetua conmemoración por don Fernando de Acuña, por aver dél recebido tan grand benefiçio. Véase, $\mathrm{M}$.
} 
En suma, pues, aunque la verdadera importancia e interés del testamento del mariscal Pardo de Cela reside sobre todo en su intrínseca significación histórica, que insisto en considerar más que notable, no por ello debe minimizarse el valor de las muchas y variadas noticias que en el mismo se contienen; las que ya han quedado resaltadas y comentadas resultan suficientemente expresivas de ello.

Mientras tanto, por lo que hace al tono general del documento, aunque también se ha señalado que no ofrece mayores singularidades en relación con lo que por entonces era costumbre asentada, creo que merece la pena llamar la atención aquí sobre el conjunto de las denominadas cláusulas civiles o dispositivas y, más en particular, sobre la naturaleza y escasa relevancia patrimonial de la mayor parte de las mismas, pues no parecen corresponderse muy bien con la posición de poder y la propia preeminencia social que al señor Mariscal se le reconocía en el concierto de la nobleza gallega de la segunda mitad del siglo XV. Mas bien parecen poner de relieve otra muy diferente, menos encumbrada y geográficamente más localizada. Sin duda había otros bienes y sobre todo muchas otras rentas y juros que no se especifican, pero que cabe suponer estarían incluidas en la masa patrimonial de las dos herederas. Sin embargo, la anterior apreciación cobra nuevo sentido al advertir, en el conjunto del testamento, la ausencia de ciertas cláusulas y detalles usuales entre quienes también disfrutaban de aquella posición de privilegio; apunto, en este sentido y sólo como mera ilustración, el recurrido uso de la condición de vasallo de noso señor el rey, que el propio Mariscal sí consta haber exhibido en ocasiones anteriores, o el arbitrio de ciertas medidas o fundaciones destinadas a preservar la memoria propia y a fortalecer la que corresponde al linaje, además de las consabidas disposiciones que recuerdan — a veces de forma calculadamente ordenada - a hermanos, padres, abuelos y otros allegados, o las que premian o encomiendan el cuidado y protección de escuderos y servidores, sin olvidar aquellas otras que tienen por objeto garantizar la integridad del patrimonio y la continuidad misma de la casa et estado, dado que en este caso concreto no correspondían las consabidas recomendaciones al primogénito heredero de la misma. Nada de todo esto, en efecto, se incluye con términos precisos en el testamento del mariscal Pardo de Cela, bien porque las difíciles circunstancias del momento en que fue otorgado sólo le permitieron atender a lo sustancial el descargo de su conciencia y poco más_-, o bien simplemente porque aquella

Diego de Valera, Crónica de los Reyes Católicos, edición y estudio por Juan de M. Carriazo, Madrid, Junta para Ampliación de Estudios. Centro de Estudios Históricos, 1927 (Revista de Filología Española. Anejo, 8), Cap. XXXV, págs. 103-104. 
posición y preeminencia tenían en su caso un carácter o sentido diferentes, pues ni le correspondían por la importancia de su linaje, aunque el suyo era de los antiguos y reconocidos, ni tampoco por la posesión de un gran patrimonio familiar perfectamente consolidado ${ }^{46}$. En cualquier caso, las ausencias que quedan señaladas aquí marcan una clara diferencia, que importa destacar, con respecto a los testamentos otorgados por otros grandes personajes gallegos de la época; valgan como ejemplo, entre los más conocidos, los de Payo Gómez de Sotomayor y su hijo el mariscal Suero Gómez de Sotomayor (1454 y 1485 ${ }^{47}$, Ruy Sánchez de Moscoso y su segundo nieto don Lope Sánchez de Moscoso, primer conde de Altamira (1454 y 1500) ${ }^{48}$, don Sancho de Ulloa, primer conde de Monterrey (1480) ${ }^{49}$ o don Diego Pérez Sarmiento, segundo conde de Santa Marta, y su hijo don Bernaldino Sarmiento, conde de Ribadavia $(1465 \text { y } 1493)^{50}$.

\section{APÉNDICE}

Nota de la edición:

Como ya se ha anticipado más arriba, el más cercano al original de los tres traslados aquí editados es, sin duda, el que se incluye como número 1, por ser el mejor transcrito o el "trasladado" con mayor rigor, a pesar de las inexactitudes y errores

\footnotetext{
${ }^{46}$ Aponte precisa cuál era el poder que exhibían de los Pardo de Cela de Betanzos: Juan Pardo de Amaya (padre de Pedro Pardo o mariscal), con seis o siete escuderos y dosçientos hombres, vasallos y beatrías; y su hermano, Lope Núñez de Montenegro, con quatro o çinco escuderos y cincuenta vassallos. Sin embargo, el Mariscal lograría hacerse en tierras de Mondoñedo y Vivero con unas muy buenas rentas - principalmente reales y episcopales - y mostrarse, ya como gran señor, con un poderío militar al alcance sólo de los grandes señores gallegos. El mismo Aponte lo precisa también, al tratar de Sancho Sánchez de Ulloa, conde de Monterrey, pues recuerda que este último estaba confradado con Pedro Pardo, mariscal, cuya casa era de muy buenas çinquenta lanças y que ajuntaba quatro o cinco mil peones, añadiendo de seguido que el Mariscal no comía dinero dél, porque comía todo el obispado de Mondoñedo. Véase, Vasco de Aponte, Recuento de las casas antiguas del Reino de Galicia, Introducción y edición crítica a cargo del Equipo de Investigación "Galicia hasta el 1500" integrado por Manuel Díaz y Díaz et al., Santiago de Compostela, Consellería da Presidencia, Servicio Central de Publicacións, 1986, 135, pág. 151, y 180-181, pág. 167. ${ }^{47}$ Véase, Colección Diplomática de Galicia Histórica, doc. CVII, págs. 460-471 y doc. X, págs. 35-58.

48 José García Oro y María José Portela Silva, La casa de Altamira durante el Renacimiento, Santiago de Compostela, El Eco Franciscano, 2003, págs. 90-96 y 106-127; véase también Colección Diplomática de Galicia Histórica, doc. XXIV, págs. 97-101.

${ }^{49}$ Véase, Colección de documentos históricos del Boletín de la Real Academia Gallega, vol. I, La Coruña, Real Academia Gallega, 1915, doc. CVIII, págs. 307-316. Un segundo testamento, más tardío, en Colección Diplomática de Galicia Histórica, doc. LXXVI, págs. 324-347.

${ }^{50}$ Véase, Gonzalo Francisco FernándeZ SuÁreZ, La nobleza gallega entre los siglos XIV y XV, Santiago de Compostela, El Eco Franciscano, 2002, docs. 28 y 48, págs. 429-435 y 537-549.
} 
que contiene, todas fácilmente detectables para los abezados en este tipo de escrituras. El incluido como número 2, por su parte, es un traslado del traslado realizado por el notario Pedro López de Sahagún. En él van subrayadas las alteraciones apócrifas o añadidos sustanciales, además de las otras inexactitudes de lectura que se han detectado. El incluido como número 3, por último, es otro traslado posterior realizado sobre el mismo documento original utilizado para el número 1.

Aunque se trata de traslados notariales "de bervo ad verbo", en los mismos se contienen numerosos errores de lectura por parte de los funcionarios de la Audiencia, circunstancia muy habitual debida a descuidos o a una simple falta de pericia.

Para la presente edición se han seguido las normas habituales ${ }^{51}$. Como complemento, dada la naturaleza de esta edición, los subrayados deberán entenderse como añadidos sustanciales de carácter apócrifo — véanse en el documento número 2-o simples alteraciones en la transcripción del documento trasladado. Para lo demás deberá advertirse lo siguiente:

- El fin de renglón en el original se indica con «I» y el de página con «\|».

- Las frases o palabras escritas entre renglones se transcriben en letra normal entre $\backslash /$.

- Los caracteres no presentes en el texto, pero precisos para su sentido se transcriben entre ángulos $<>$.

- No se indican las palabras abreviadas.

- Las indicaciones referentes al texto se escriben en letra cursiva entre paréntesis (cursiva).

- Las grafías aberrantes, repetidas o destacables se señalan con cursiva seguida de un (sic).

\footnotetext{
${ }^{51}$ Se trata, en general, de los criterios adoptados por la Escuela de Estudios Medievales del Consejo Superior de Investigaciones Científicas (Normas de transcripción y edición de textos y documentos, Madrid, Escuela de Estudios Medievales, CSIC, 1944), adaptándolas a las "Normes internationales pour l'edition des documents medievaux" (Commission Internationale de Diplomatique et COMmission InTERnATIONALE De Sigillographie, Diplomatica et Sigillographica: travaux préliminaires de la Commission Internationale de Diplomatique et de la Commission Internationale de Sigillographie: pour une normalisation internationale des éditions de documents et un Vocabulaire international de la Diplomatique et de la Sigillographie, Zaragoza, Cátedra Zurita de la Institución Fernando el Católico, d.l. 1984 (Folia Caesaraugustana, 1) y a las características específicas de los documentos escritos en gallego, cuyo sistema abreviativo y anárquica ortografía proporcionan combinaciones que muchas veces escapan a la lógica paleográfica (Manuel LuCAS Álvarez, "Para unas normas complementarias de transcripción de documentos en gallego", Cuadernos de Estudios Gallegos, 12 (1949), págs. 95-110 y "Paleografía gallega. Estado de la cuestión", Anuario de Estudios Medievales, 21 (1991), págs. 419-470).
} 
1483, octubre, 1 y 3.- Villamayor de Mondoñedo.

Testamento y codicilo del mariscal Pedro Pardo de Cela, marido de doña Isabel de Castro, en el que instituye por legítimas y universales herederas a sus hijas doña Constanza y doña Beatriz.

VALLADOLID, ARCH, Pleitos Civiles, Escribanía de Alonso Rodríguez, caja 2595-1, papel, traslado notarial de Juan Nieto, escribano de la Audiencia de Santiago (véase fin del doc. núm. 3), sobre el documento que se consideró “oreginal de Pedro Pardo, el mariscal”, presentado por Bernaldino de Castellanos y su mujer doña Mayor de Vaamonde en la Audiencia de Santiago el 2 de agosto de 1510 ante el gobernador y los alcaldes mayores, castellano y gallego, letra procesal.

$\int$ En o nome de Deus, amen. Sepan I quantos esta carta de testamento vieren como I yo, el mariscal Pero Pardo de Çela, estando I sano del entendimiento et seso natural I qual Dios nuestro Sennor tebo por vien de I me dar, et temiendome de la muerte, I que hes cosa natural, otorgo et conosco I que fago et hordeno este mi testamento enl que demuestro la mi postrimera boluntad I a serviçio de Dios et de Santa Maria, et de I toda la corte çelestial, et creo firmelmente aquellas palabras que se contenen I en el Credo yn Deo, por la qual creençia son çierto I que la mi anima sera salva ante la faz I de mi sennor Jhesu Chisto, sy ante non, syno I al dia del muy gran juyzio, et por ende I de mi anima et de mi cuerpo et de mis I bienes fago estas mandas que se I syguen. Primeramente mando et olfresco mi anima a mi sennor Jhesu Christo, que la I crio et derrimio por la su santysima I et muy preçiosa sangre, para que faga I della lo que faran de las animas justas, I et el mi cuerpo mando a la tierra donde I fue formado, et mando que sea sepultado I en la yglesia del lugar donde yo falesçiere II desta presente vida, et mando que como mis carnes I fueren gastadas que llieven mis huesos I a San Françisco de Vibero, et los sepullten honde jaz Fernan Rodrigues d'Aguiar, mi I visabuelo; et mando a la yglesia donde I primeramente fuere sepultado tres I mill maravedis, et al dicho monesterio de San I Françisco de Vibero quinentos maravedis I de cada un anno por todo lo que ajo I en a reguera de Ferrol, los quales dichos quinentos I maravedis mando que sean para reparo de la I sacristania et libraria del dicho moneslterio, et que me digan por las fiestas I de febrero et de março et de agosto et seltienbre de Nuestra Sennora una misa cantada, I por mi anima et de mis antepasados, I et otra por dia de San Françisco, et que sean I çinco en el anno para senpre; et mando que me I fagan mis honrras et osequias I en el dicho monesterio de San Françisco I de Vibero, como pertenesçe a mi honrra I et estado. Yten mando enbiar un rolmero a Santa Maria de A Guadelupe a I mi costa, et que 
le den un quintal de çera, I et que me digan ende quatro misas canltadas et vinte rezadas. Yten mando I que me enbien a Santyago d'Espanna logo I como entrar el jubileo tres romeros, II que sean personas de buena bida, et que den a la yglesia I para la obra cada romero dozientos maravedis; et I me enbien otro romero a Santa Maria de Villavade, I et digan ende un<a $>$ misa cantada et de dozientos I maravedis para la obra. Yten mando para redenlçion de cabtibos mill maravedis. Yten a los polbres de San Lazaro de Villamayor et de I Vibero a cada < un >, çient maravedis. Yten mando quel dia I que me sepultaren que den de comer a çinlcoenta pobres, et otros tantos el dia I que mudaren mis huesos. Yten mando I que en el fuero que yo tengo de la I torre de Goyanes que paguen allende I de la posesyon que en el esta, çient maravedis I cada un anno de mas, porque soy enlcargo delo. Yten mando a Santa Maria I de Villamayor por la vinna que oube I de donna Mayor de Bamonde, que digan I de cada un anno una misa cantada en I dia de Santa Maria d'agosto. Yten I mando por el cargo que soy al molnesterio de San Salbador de I Villanueba, que le desocupo el I foro de Çeleyro et Galgaon et Quende I et Benbribe porque me perdone todo lo I que del dicho monesterio tome et lleve I fasta el presente dia, et mando a mis helrederos que non lo demanden, que yo çedo I el derecho que a ellos tengo en el dicho monesterio. II Yten desenbargo al monesterio de San Martinno I de Mondonedo, los benefiçios de Abadin I et Recaree et San Romao de Villaestrofe I que yo lleve del dicho monesterio, et mando I a mis herederos, so pena de mi maldiçion, I que nunca los demanden. Yten mando al I dicho monesterio de San Martino dos reales o I sesenta maravedis de cada un anno por lo meu I casal et heredades de Marçan, <et> que me digan I de cada un anno una misa cantada en dia de San I Pedro, et en su altar. Yten dexo et desenbargo I todos los benefiçios que levaba fasta aqui I a los clerigos en questaban puestos et a los que a ellos tenian derecho, et mando a mis herederos I que non ge los enpidan nin demanden, et pidoles I perdon por lo pasado que lleve. Yten desenbargo I la vinna da Lagoa que jaz su la torre de Gonçalo I Mendez, que fue de Juan de Pena Mosquera, I a Juan de Pena Mosqueyra, seu fillo. Yten I desenbargo las vinnas que fueron de Afonso I Yanes, capelan do obispo don Pedro, que moraba I en o Castro d'Ouros (tachado), que jazen hen o couto de I Canedo, a Afonso Yannes de Castro, clerigo de Lalgoa, et que le pidan perdon por las I nobidades pasadas. Yten a Lopo Leyron I mando que de aquellas que dize que son encargo, I que sumariamente vista su ynformaçion, I lo vea el prior de San Martinno, et determine lo I que fallar por derecho, et mando a mis herederos I| questen por lo que determinare, et aquello quel I dixere que le pertenesçe, que aquello le deslocupen. Yten desenbargo a Fernan Balea I la oytaba parte de Santa Maria de Bretonna. I Yten desenbargo las terrarias de Vale et das Riberas I de San Segun questan con todo lo que les pertelnesçen a meu sobrinno Roy Gonçales, et que se conltente con ellas por lo mas. Yten desenbargo I a min- 
na hermana Mayor Parda o quarto do I couto de Cajoto, que le pertenesçe por su madre. I Yten desenbargo la casa de San Martinno a los I hijos de Gonçal Conde, et que me paguen çinco I mill maravedis que me deben, et demanden dos mill I a Lopo do Rio, que yo le tome de mas, que mande I que se los diesen. Yten desenbargo I los vienes do de Juncal, de la marina de Byvero, que jazen en Recaree, et los de Roy I Martinez, que jazen en la dicha felegresya, I et que los llieven sus herederos et alquellos a quien pertenesçen de derecho. I Yten desenbargo la terreria I de Santa Cruz a la muger que fue de I Pero de Magarinos, cuya ella es I et le pertenesçe de derecho. Yten I mando dar quinentos maravedis al molnesterio de Santo Domingo de Bibelro, de una binnaque fue de frey Ruy I Becoz (sic), que le soy obligado. Yten II desenbargo al sennor probisor el presltamo de Fitoyro et bodos (sic) de Bretonna, I por quanto conosco quel tenia et tiene I a el derecho, et a San Juan de Uveda, et que I aquel por quien los llevaba non telnia justiçia. Yten desenbargo la I casa et binna de Fernan Yanes de Relqueyxo que jaz en Santo Adrao al I dicho Fernan Yannes. Yten a Santa I Maria de Baldeflores trezientos I maravedis para una pitança. Yten a los I espitales de Vibero et Villamayor, a cada I uno, diez maravedis. Yten mando a las I yglesias de Galdo et Magaços et Chalbin, a cada una, un caliz que pese un I marco et medio de plata. Yten I mando a minna moller dona Ysabel I de Castro la mi posa de Çendemill, I con todas las heredades et casares, et I et ( sic) con los casares de Pereyro et I binnas del Balle d'Oro et terraria de Relcarey por dias de su bida, et despues I que quede todo desenbargo a mis helrederos. Yten por quanto soy I obligado al monesterio de Sant I Martinno de una casa de refortorio que hende I esta derribada, mill et quinentos I maravedis para que la reparen. Yten desenbargo || los vienes de Ruy Barata a sus herederos, I o a quen pertenesçeren de derecho. Yten I mando dezir en la yglesia de Villamayor tres I trintanarios por las animas de Lopo Lopez I et Roy Diaz et Diego Teyxeyro, et mando I por ellos nobeçientosmaravedis. Yten I mando a mis herederos que dexen las casas I de Bibero en que mora Pero Lopez de San I Fagund al dicho Pero Lopez por dias de su I bida, et despues que fique a mis herederos. Yten I mando que todos los que benieren deziendo que yo I les soy obligado et mostraren como les soy I obligado por recabdo çierto, mis conplildores durante su tenpo les satysfagan, I et despues mis herederos que $<0$ tal> satysfagan. I Yten mando que paguen al bachiller I de la gramatyca Gonçalo Garçia dos I mill maravedis que le son a cargo, et le pido por Dios que me I perdone lo mas. Yten desenbargo a Roy I Basquez, canonigo, la parte del benefiçio I que le cabe de Santa Çeçilia, de quel es clerigo, I con el pan de oganno que le pertenesçe <a> aquella I parte de quel es clerigo. Yten mando deslenbargar a Juan de Quende, fillo de I Juan Yanes, capelan, los bielnes que fueron de su padre segun I questan desenbargados por mi carta. II Yten mando a Garçia d'Estoa, canonigo, allende I de la otra satysfaçion que le tengo hecha, dos jorlnales de 
binna questan en Canedo que fueron de I Leonor do Carballal, et que pague mill maravedis I para conplimiento de mi testamento. Yten I çerca de la plata que Diego d'Andrade delmanda, el nunca puso tal plata en mi mano; I mi muger et Pero Lopez de San Fagun salben la plata que fue puesta en mi mano, I et de aquella plata mando que le saltisfagan, et lo que dello se me acuerda I es un taçon grande que oube de Garlçia Lopez, et dille por el tres mill maravedis, I et oube otro pichel de plata de Pero I Afonso das Seyxas, et dinlle por el tres mill maravedis, et mas ube una cadena de I oro de Fernan Perez d'Andrade, et delbiame por ella dez mill maravedis, la qual caldena rovaron los viscayno $<$ s $>$ quando I entraron en Bibero: o que fuere derelcho çerca desta cadena se faga porlque fue robada a mi con otras cosas; I dize Diego d'Andrade que me pago I destos maravedis, non se quantos; todo lo que I juraren aquel que dixere que me los I pago, esten a su juramento, et tomellos en cuenta de lo que me deben de la plalta d'arriba, et sy en mas fuere obligado, II mas paguen mis herederos. Yten mando I que sepan de Pero Lopez de San Fagun lo I que me presto Ares Pardo y tanbien selpa lo que le tiene pago et resçebido en culenta, et sy algo quedare, mando que ge lo palguen. Yten mando que paguen a Fernan I Balea, canonigo, dos mill et seysçienltos et sesenta maravedis dos çinco mill que me I presto para fazer la pagua al sennor I don Fernando. Yten mando çerca I de lo que me hera obligado Rodrigo I Gonçales de Camara, canonigo, por sus bielnes, que paguen quatro mill maravedis para el I conplimiento de mi testamento, et desenbarlgole todos sus bienes et casas para que los I aya Bilinda, su fija. Yten mando el I mi foro de Gontan a Juan Lopez Pardo, I hijo de Lopo Garçia de Villaousaz, mi I sobrinno, et mando que le dian el fuero I porquel esta nonbrado en el. Yten mando I que quanto a los prebillegios de Canedo I que tiene mi muger, si non fueren contenltos mis parientes que ella los tenga, que eslcojan todos una presona (sic) fiable que los I tenga en fialdade por todos. Yten I fago mis cabeçaleros (un tachón en medio de palabra $)^{52}$. et conplidores I desta mi manda et testamento a la dicha I donna Ysabel de Castro, mi muger, et a Ruy I Gonçales de Ribadeneyra, mi sobrynno, a I anbos et dos juntamente, a los quales pongo || et apodero en todos mis bienes muebeles et I rayzes para que sin mandamento de juez I nin de alcalde ayan libre et conplidopoder I para entraz (sic) et tomar que tantos dellos I quantos ellos quisieren et por ven tobieren, I et los puedan vender et rematar para I que de lo que balieren et por ellos dieren cunlplan et paguen todo lo contenido I en <e >ste testamento; en speçial les dexo el dicho I poder para bender el mi lugar de I Galdo que conpre a Pero de Pumarinno, I vezino de Santa Marta, et por el cunlplan mientre (sic) vastare, et lo mas resltante cunplan por todos los otros I mis bienes. Et mando et desenpacho al I dicho Roy Gonçales, mi sobrino, por su trabajo I et

\footnotetext{
52 (Al pie) Va hemendado o dize "cabeçaleros", vala.
} 
afan deste mi conplimiento, et porlque le soy encargo por la parte que calbia a su madre, el mi palaçio et et (sic) binnas I et heredades que yo tengo en Santa Marina I das Negradas. Yten mando a Maria I Lopez de Vilamoor, muger de Pero de Bilbero, tres mill maravedis en satysfaçion de lo I que le soy encargo, y ruegole por I amor de Dios que perdone lo mas. I Yten nonbro por voz en el fuero del coto I de Frejulfe a Juan Nunez Pardo, mi I hijo, para que lo aya et llieve con las I vozes que tiene despues de la muerte I de la dicha donna Ysabel, mi muger, porques II mi boluntad qu'ella, en su bida, lo llieve, et despues I de su muerte que lo aya el dicho Juan I Nunnez Pardo, mi hijo. Et mis mandas I et misiones conplidas et acabadas et debldas pagas, abiendo cada uno lo que de I suso le yo mando por este mi testalmento, en todos los otros mis bienes muebelles et rayzes remanesçientes, fago I et dexo et constituyo et establesco por I mis legitymas universales herederas I a donna Costanca et a donna Beatriz, mis I legitimas hijas et de la dicha donna Ysalbel, mi muger, para que los ayan et lielven et hereden con la vendiçion de I Dios et mia, et los partan et devidan hermalnamente de por medio, et les mando so I pena de mi bendiçion, que ellas se amen I una con la otra como buenas hermalnas, quitando d'entre sy todo rigor et I escandalo, pleytos, letijos et deslcordias; et ruego et pido a la sennora I donna Ysabel, mi muger, que asy $\mathrm{g}<\mathrm{e}>$ lo mande l et rogue, et que asy lo cunpla, anlsy questa mi boluntad. Et esto do et otorlgo por mi testamento et ultima et I et (sic) postromera boluntad conplida et alcabada, para que se cunpla et guarde l et pague segun que de suso en este mi I testamento se contiene, en todo tienpo I del mundo donde quera que paresçiere II en juyzio et fuera del, et sy alguna persona I asy de mi parte como de la estranna beniere I para quebrantar et emenguar (sic) et anular I este dicho mi testamento et alguna parte del, I arriedolo et apartolo de la parte que de los I dichos bienes mios aya de aber et diga I que le pertenesçen con çinco soldos a I cada uno, et demas <que> aya de la voz de los I dichos bienes, que los no ayan nin hereden mas, I que demas que aya la mandiçion (sic) de Dios I Padre Todopoderoso, et de los vienabenlturados San Pedro et San Pablo I et la mia, que les non canse fasta la seltima generaçion, et las sus animas I sean condenadas con Satan et Abiron I et Judas el traydor en el fuego ynfernal I para syenpre jamas, donde I nunca ayan redençion; et todabia I et en todo tenpo este mi testamento et I ultima boluntad balga et quede et este I firme en su fuerca (sic) et vigor, et todo lo que I yo en <e>lla mando sea fecho et conplido I en todo et po $<$ r $>$ todo; et sy non baliere como I testamento balga como codiçillo, I et sy non baliere como codiçillo quero I et mando que balga como ultima I et postromera boluntad.

Yten I desenbargo et desenpacho a Maor Parlda, mi hermana, la mitad del casal da Lamallvella. Yten mando que sastysfagan a Voliçion (sic) lo I que el mostrar que le yo lleve o otros por min. I Yten mando que mis herederos et conplildores se acuerden et conçierten con los I libros de mis cuentas, et todo lo 
que se fallare I que yo debo o me deben que me refiero a I ellos en las escripturas abtenticas I et albalaes que paresçieren firmados. I Yten mando que Gonçalbo Yannes, I canonigo, lleve un tonel de vino que eu I tenno en Bilajuane en sastysfaçion de una I meda que le tomey en Bilarmea, et le pido I perdon por amor de Dios.

Que fue fecho I et otorgado en la çibdad de Villamayor I de Mondonedo, el premero dia del mes de I otubre del anno de mill et quatroçientos et I ochenta et tres annos ${ }^{53}$.

Testygos que fueron I presentes, llamados et rogados: el reberendo I sennor Albaro Garçia de Luarca, balchyller en decretos et probisor en la yglesia I de Mondonedo, et don frey Fernando I de Bolanno, ministro de la probençia I de Santyago, et administrador del I monesterio de Villanueba, et I Fernan Balea, canonigo, et Gonçalvo Yanes I et Diego Fernandez de Labrada, canonigos, I et Roy Garçia, suchanter, et Martin Vasques, I clerigo, et Gil de Baracaldo, et Juan Sanches I de Carion, clerigo de la diocesis de Palençia, I et Miguel Sanches de Bobadilla, II et Galor de Baçan, et Christobal de Mata, et Pero Xaralmillo, escuderos et criados del rey, nuestro I sennor.

$\int$ Et despues desto, a tres dias del dicho I mes de otubre del dicho anno de mill et quatrolçientos et ochenta et tres annos, en la dicha çibdad I de Villamayor de Mondonedo, en presençia I de mi, el notario et testigos de yuso escriptos, el dicho I sennor Mariscal hemendando en el dicho su testalmento a manera de codiçillo, mando esto que se I sygue: yten mas yo, el dicho Mariscal, I hemendando en mi testamento a modo de codiçillo, I mando la terçia de las vinnas de San Estebo, I segun questan por la manda de mi padre I Juan Pardo, que Dios aya su anima, a I meu sobrinno Juan Nunnez, et mandole mas I dez mill maravedis para hemenda et satysfaçion I dos seus que comi, et demandole perdon por amor I de Deus por lo mas porque enbengar la muerte I de su padre et guerras et questiones, enl el gastey mas et (tachado) que por aquella cabsa o meu, et mas I gastey do meu, et mandolle so pena de la mi I (un tachado) bendiçion, que no aya mas question nin delmanda con mis hijas sobresto, et el I ben sabe que los vienes que llieve son la mayor I parte de los vienes que mi padre avia. Yten I mando que por quanto Afonso de Santa Marynna (un tachado en la palabra) $\|$ beo a min (al margen) ${ }^{54}$ et me dixo que cojera por min las alcabalas de Vale et de Sanlta Marinna, et dize que me las pagou, mando que quantoel I probar et jurar que me pago dellas, que las paguen, I et eso mismo quanto demostrar que me pagou I dos reales do ome que morreu en Bal<e $>$ en lo mar, que tanto I lle paguen sy el probar que me los pagou o lo I fezer por su juramento. Yten por quanto yo I lleve algunas cosas de

\footnotetext{
53 (Al margen) Fecha.

54 (Al pie) Va en la margen o dize "veo a mi", vala.
} 
casa de la madre I de Afonso de Vibeyro de Balladolid, que le mando I dar a sus herederos seys mill maravedis, et se non I fueren contentos, que saquen pesquisa et I lo que fallaren que les soy obligado, esto I les paguen. Yten mando dar a Diego I de las Riberas, por un negro (sic) que obe de su paldre, dos mill maravedis. Yten mando que duas bacas I questan en casa de Pero, juyz, en Muras, que son de Afonso Yannes do Castro, que bayan por ellas et I ge as den. Yten mando que ayan conta con Alvaro I do Freyxo, et se se fallar que eu lle soo oblilgado de bacas ou de alguna cousa, que ge lo I paguen; et quanto a las bacas que le dio mosen I Mudarra que yo lleve, estas mosen Mudarra me I las dyo et por esto las tome. Yten mando I dar a Juan do Naseyro, carniçeyro, dozentos I maravedis que le debo de carne. Yten por quanto I yo lleve a Juan Rodrigues, clerigo del Castro d'Ouro, I quatro mill maravedis, mando que ge los den et palguen. Yten por quanto yo mande que Belinda, II fija de Rodrigo de la Camara, me pagase quatro I mill maravedis et le desocupava çiertas cosas, I et ( sic) le quito mill dellos, et sean tres mill los I qu'ella ha de dar. Yten mando a meu solbrinno Fernan Pardo las minnas praças que jazen I en Bibeyro a la puerta de San Françisco, que jazen I enfruente de las casas que fueron de Lopo Diaz I de Pantin. Yten mando a Juan Pardo, I el bastardo, hijo de Juan Nunnez, mi herlmano, un casal que yo tenno en Çela, que sollia llevar Diego de Çela, questa a sua I porta. Yten rogo et mando a mis herelderos por la mi bendiçion et so pena de I maldiçion que non ocupen nin tomen el colto de Frejulfe a Juan Nunnez Pardo, mi I fijo, porque yo lo fize et nonbre por voz I et persona del, et mando que moriendo el menor I de hedad, que quede a mis herederos, et que I a la muerte de mi muger, que lo llieve Alonso Avade, I fasta quel sea de hedad. Yten mando saltisfazer a los herederos de Roy Diaz I et Lopo Lopez et Diego Teyxeyro quatro I caballos, lo que fuere razonable. Yten I mando que por quanto Tomas dize que yo le I soy encargo de çiertos maravedis que le tome, o I mis honbres por mi mandado, que lo quel I probare le satysfagan. Yten mando II que por quanto en el fuero de Andeon porque mi hija I donna Beatris esta por persona nonbrada en el, I que yo asy la nonbro et ge lo desenbargo. Yten I por quanto yo soy encargo a muchas persolnas que me non acuerdo para mandar satysfazer I a cada una partycularmente, que yo mando I que los que mostraren que yo les soy encargo, que mis helrederos le satysfagan por mis bienes, et non I queriendo delos asy asy (sic) fazer o non queriendo I açebtar mis bienes et herençia, que yo hago I et estatuyo por mis herederos <a> aquellos que asy I soy encargo fasta que sean pagos.

Que fue I otorgado este codiçillo anno, dia I et mes et lugar susodichos por el dicho I sennor Mariscal.

Testigos que fueron presenltes, <lla>mados et rogados: Ares Peres, prior I de Sant Martinno, et Fernan Balea, canolnigo, et Gil de Baracaldo, et Fernan de I Balera, et Galaor, et otros. 
Et yo, I Diego Perez, notario publico dado I do sennor obispo de Mondonedo en a çibdad I de Villamayor <et> en todas las otras villas I et lugares do seu obispado, a todo lo susoldito con los dichos testigos presente fue I en este testamento, et por outro fize escripvir I por rogo et mandado et a pedimiento || de Rodrigo Gonçales de Ribadeneyra, et por I ende puse aqui meu nome et synal acosltumado, en testimonio de verdade, rogado et relquerido para ello.

Diego Peres, notario.

\section{2}

1483, octubre, 1 y 3.- Villamayor de Mondoñedo.

Traslado otorgado en Vivero el 3 de diciembre de 1483 por Pedro López de Sahagún, escribano y notario publico del rey, del testamento y codicilo del mariscal Pedro Pardo de Cela, marido de doña Isabel de Castro, en el que instituye por legítimas y universales herederas a sus hijas doña Constanza y doña Beatriz.

VALLADOLID, ARCH, Pleitos Civiles, Escribanía de Alonso Rodríguez, caja 2595-1,papel, traslado notarial otorgado en Santiago el 18 de junio de 1510 estando en la Audiencia los alcaldes mayores, y presentado por Juan de Villanueva en nombre del Obispo de Mondoñedo; ante la petición de este último de recoger la escritura, se volvió a hacer traslado con presencia de la parte contraria por parte de Alvar Núñez, secretario, el 27 de junio de 1510, castellano y gallego, letra procesal.

Observaciones: se transcriben en letra de menor tamaño las cláusulas del traslado realizado por Pedro López de Sahagún. Se subrayan, asimismo, las alteraciones, añadidos apócrifos o distorsiones con el tenido como verdadero, que llevaron a considerar espúreo este documento en el proceso.

En la villa de Vibero, a tres días del mes I de dizienbre, anno del nasçemiento I de nuestro Sennor Ihesu Christo de mill et quatrolçientos et ochenta et tres annos, este I dicho dia estando delante de las I puertas de las torres de la I dicha villa el sennor Fernan I Çeron, corregidor que hes della por el I noble caballero don Henrique I Enryquez, tenedor que hes della I por sus altesas, et en presençia I de mi, Pero Lopez de Sahagun, I escrivano et notario publico del I dicho sennor rey en la su corte et en I todos los sus reynos et sennorios, I et de los testigos de yuso escriptos, palresçio ende presentes antel dicho sennor I corregidor la sennora dona Ysabel I de Castro, muger que fue del dicho mariscal I Pero Pardo de Çela, ya defunto, que Santa I Gloria aya, et con ella Roy Gonsales I de Ribadeneyra, cabeçales et conplidores $1{ }^{55}$ que se dizian ser del dicho Mariscal, et pre-

\footnotetext{
55 (Arriba, en anotación posterior) El testamento del mariscal que presentó la parte del obispo, I es treslado.
} 
sentaron I antel dicho corregidor una carta de testamento I fecha et otorgada por el dicho sennor I Mariscal escriptas en papel, synada del I sygno et suscreçion de Diego Peres de I Mondonnedo, notario del sennor obispo de I Mondonnedo, segun que por ella paresçia, I de la qual su thenor de verbo ad verbo es este que se I sygue ${ }^{56}$

En el nonbre de Dios, amen. Sepan quantos I esta carta vieren como yo, el mariscal I Pero Pardo de Çela, fazo seyendo I sano et con todo mi seso et entendimiento I conplido qual mi Sennor Jhesu Christo tubo I por bie $<$ n $>$ endede me dar, et temendome de la I muerte que acerca tengo de pasar, el qual I testamento fazo en esta esta manera que se sygue. I Primeramente mando mi alma a Dios, I que la conpro <et> criou, et rogo a la I Virgen Maria con todas las Birgines I que sean mis abogadas, et rogo a los I sennores San Pedro et San Pablo que me I absuelban la mi alma, et ruego al I sennor San Miguel et San Grabiel I que sean mis abogados a la ora de I minna muerte. Yten mando sepultar II minnas carnes en el logar donde falesçiere I de la presente vida. Yten mando como mis carnes I fueren gastadas que llieven mis huesos I a Sant Françisco de Vibero, et los sepulten I honde jaz Fernan Rodrigues d’Aguiar, mi | visahuelo. Yten mando a la yglesia | donde primeramente fuere sepultado | tres mill maravedis, et al dicho monesteryo de San I Françisco de Bibero quinentos maravedis de cada I un anno por todo lo que he en la reguera I de Ferrol, los quales dichos quinientos I maravedis mando $\backslash$ para reparo $/^{57} \mathrm{~d}<\mathrm{e}>$ la sancristanya et lilbreria del dicho monesterio, et que me I digan por las festas de febrero I et março et agosto et setienbre I de Nuestra Sennora una misa cantada, por I minna alma et de mis antepasados, I et otra por dia de San Françisco, que sean I çinco en el anno para syenpre. Yten I mando que me hagan mis honrras et olsequias en el dicho monesterio de San I Françisco de Bibero, como pertenesçe a I mi honrra et estado. Yten mando I enbiar un romero a Santa Maria de I A Guadelupe a mi costa, et que le den un I quintal de çera et me digan ende quatro I misas cantadas et vinte rezadas. I| Yten $<$ mando $>$ que enbien a Santyago d'Espanna I luego como entrar en el jubeleo tres rolmeros que sean personas de buena bida, et que I den a la yglesia para la obra cada rolmero dozientos maravedis, et otro a Santa I Maria de Bilabade, et digan ende una misa I cantada et $d e<n>$ dozientos maravedis para la olbra. Yten mando para redençion I de cabtybos mill maravedis. Yten a los I pobres de San Lazaro de Billamayor I et de Bibero a cada $<u n>$, çient maravedis. Yten I mando quel dia que me sepultaren que I den de comer a çincoenta pobres, et oltros tantos el dia que mudaren mis I huesos. Yten mando que en el fuero I que yo tengo de la torre de Guayans

\footnotetext{
56 (Al margen, en anotación posterior) Testamento del I mariscal.

${ }^{57}$ Va entre renglones u dise "para reparo".
} 
| que paguen allende la pensyon çient (tachado $)^{58}$ que en el esta, çient maravedis cada un anno de I mas, porque soy encargo dello. Yten I mando a Santa Maria de Villamayor I por la vinna que ube de donna Mayor I de Bamonde, çient maravedis, porque dygan I de cada un anno çient (tachado) una en (tachado) misa cantada I en dia de Santa Maria de agosto. Yten I por el cargo que soy al monesterio de I San Salvador de Villanueba que le desocupo I| el fuero de Çillero y Galgaon (enmendado $)^{59}$ y Quende y Benbribe porque me perdonen todo lo que del dicho I monesterio tome y lleve fasta el I presente dia. Yten mando a mis herederos I que non le demanden, que yo çedo el derecho que a ellos I tengo en el dicho monesterio. Yten deslenbargo al monesterio de San Martinno I de Mondonnedo los benefiçios de Abaldin et Racarey et San Romao de I Villastrofe que yo llebe del dicho monesterio, I et mando a mis herederos, so penna de mi I maldiçion, que los non demandar. I Yten mando al dicho monesteryo I de San Martinno dos (enmendado) reales o sesenta I maravedis de cada un anno por lo meu casal I et heredades de Marçan, et que me digan I de cada un anno una misa cantada en I dia de San Pedro en el su altar. Yten I dexo et desenbargo las terrarias et belnefiçios que llevaba aqui al sennor I obispo de Mondonedo et a los clerigos en que I estaban puestas et a los que a ellas I tienen derecho, et mando a mis herederos I que non ge los enpidan nin demanden, et pidoles I perdon por lo pasado que lleve. Yten I| desenbargo la vinna da Lagoa que jas so la torre de Gonçalvo I Mendez, que fue de Juan da Penna Mosquera, a Juan da I Penna Mosquera, seu fillo. Yten desenbargo I las binnas que fueron de Afonso Yannes, calpelan do obispo don Pedro que moraba I en lo Castro d'Oro, que jazen en el coto de Calnedo, a Alfonso Yannes do Castro, clerigo I da Lagoa, et que lle pidan perdon por las nobildades pasadas. Yten a Lopo Leyton I mando que de aquella $<$ s $>$ binnas que diz que lle soy I encargo, que sumariamente vista su ynlformaçion, lo vea el prior de San I Martinno, et determine lo que fallare por derecho, l et mando a $\mathrm{mi}<\mathrm{s}>$ herederos questen por lo I quel determinare, et aquello quel dixere I que le pertenesçe, que aquello le desocupen. I Yten desenbargo a Fernan Balea et (sic) la oytaba I parte de Santa Maria de Bretonna. Yten I desenbargo las terraryas de Valee et das I Ribeyras de San Segun questan <con> todo lo I que le pertenesçe a meu sobrinno Roy I Gonçales, que se contente con ellas por lo I mays. Yten desenbargo a Mayor Parda, I mina hermana, lo carto do couto de I Cajoto, que le pertenesçe por sua | madre. Yten desenbargo la casa || de San Martinno a los fijos de Gonçalo Conde, I et que me paguen çinco mill maravedis que me deben, I et demanden dos mill maravedis a Lope de Rio que I yo le torne de mas, que mando que ge los diesen. I Yten desenbargo os beens de do Juncal I da marinna de Bibero, que

\footnotetext{
${ }^{58}$ Va testado en dos partes, o desya "çient", va<la>.

${ }^{59}$ Va hemendado sobre raydo o dize "Galgaon" et "dos", vala.
} 
jaz en Recarey, et los de I Roy Martines? que jazen en la dicha felegresya, I et que los llieven sus herederos et aquellos I a quien pertenesçieren de derecho. I Yten desenbargo la terrarya de I Santa Cruz a la muger que fue de Pero I de Magarinnos, cuya ella hes et le pertenesçe de derecho. Yten mando I dar quinentos maravedis al monesterio I de Santo Domingo de Vibero, de una I binnaque fue de frey Ruy Leal, que le I so obligado. Yten desenbargo I al sennor probisor el presitamo de Fitoyro et bodos (sic) de Bretonna, I por quanto conosço quel tenia a (tachado) et I tiene a el derecho, et San Juan de Ubeda, I por que aquel por quien los llevaba I non tenia justiçia. Yten desenbargo I la casa et binna de Fernan Yannes de I Requeyxo, que jaz en Santo Andrao, I al dicho Fernan Yanes. Yten II a Santa Maria de Baldeflores trezientos I maravedis para una pitança. Yten a los eslpitales de Vibero et de Villamayor, a cada I uno, diez maravedis. I Yten mando a las yglesias I de Galdo et Magaços et Chavin, a cada una, I un caliz que pese un marco et medio de plalta. Yten mando a minna moller dona I Ysabel de Castro la mi posa de Çindemill, I con todas las heredades et casares, et con los I casares de Pereyro et vinnas de Valle I d'Ouro y terraria de Recarey por I dias de sua bida, et despues que quede todo I desenbargo a mis herederos. Yten I por quanto soy obligado al molnesteryo de San Martinno de una I casa de refertorio que hende esta derribada, I mill et quinentos maravedis por que la reparen. I Yten desenbargo los bienes de Ruy Balrata a sus herederos, o a quien perltenesçan de derecho. Yten mando I dezir en la yglesia de Villamayor tres I trintanarios por las animas de Lolpo Lopez et Roy Dias et Diego Tejero, I et mando por ellos nobeçientos maravedis. I Yten mando a mis herederos que dexen I las casas de Vybero en que mora Pero Lolpes de Sahagun al dicho Pero Lolpez por dias de su bida, et despues que fillquen a mis herederos, et sy non se las quisieren I dexar, que le paguen todo aquello quel jurare I et mostrare que le yo debo et son obligado. I Yten que todos los que benieren deziendo I que yo lles soy obligado et mostraren I como les soy obligado por recabdo çierto, que mis herederos durante su I tienpo los satyfagan, et despues I mis herederos los satisfagan. I Yten mando que paguen al bacheler I de la gramatyca Gonçalvo Garçia dos mill I maravedis que le soy a cargo, y le pido perdon que me perdone lo mas. Yten I desenbargo a Roy Vasques, canonigo, I la parte del benefiçio que le cabe de Santa I Çeçelia, de quel es clerigo, con el pan I de oganno que pertenesçe $<$ a $>$ aquella I parte de quel es clerigo. Yten mando deslenbargar a Juan de Quende, fijo de Juan I Yannes, capelan, los bienes que fueron I de su padre segun estan desenbarlgado $<\mathrm{s}>$ por mi carta. Yten mando a I Garçia d’Estoa, canonigo, aleende I de la otra sastifaçion que le tenlgo fecha, dos jornales de vinna questan I en Canedo que fueron de Lionor Carballla, et que paguen mill maravedis para conlplimiento de mi testamento. Yten çerca da I plata que Diego d’Andrade demanda, II el nunca puso tal plata 
en mi mano ny muger, et Pero I Lopez de Sahagun sabe la parte que en mi mano I fue puesta daquella plata, mando que les saltisfagan, et lo que dello se me acuerda, I es de un taçon grande que ube de Garçia Lopez I et dile por el tres mill maravedis, et ube otro pilchel de plata de Pero Afonso das Seyxas I et dile por el tres mill maravedis, et demas I ube una cadena de oro de Fernan Perez de Andrade, et debiame por ella diez mill maravedis, I la qual cadena robaron los vyscaynos I quando entraron en Bibero; lo que fuere I de derecho çerca desta caldena se faga porque I fue robada a mi con otras cosas, dize Diego $\mathrm{d}^{\prime}$ Andrade que me pago destos maravedis no se quantos, todo lo que jurare aquel que dixere I que me los pago, esten a su juramento, et tomen I a (tachado) los en cuenta de lo que me debe de la plata I de arriba, et sy en mas fuere obligado, I mas paguen mis herederos. Yten mando I que sepan de Pero Lopez de

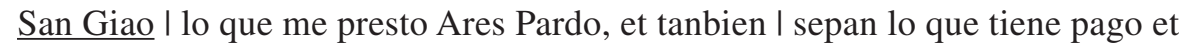
reçeballos en cuenta, et sy algo quedare, mando I que ge lo paguen. Yten mando que paguen I a Fernan Balea, canonigo, dos mill et I seysçientos et sasenta maravedis de los çinco mill I maravedis que me presto para fazer la paga I al sennor don Fernando. Yten mando II çerca de lo que me hera obligado Roy Gonçales I de la Camara, canonigo, por sus bienes, I que pague quatro I mill maravedis para conplimento I de mi testamento, et desenbargole todos sus I biene $<$ s $>$ et casas para que los aya Belinda, su I hija. Yten mando el mi fuero ${ }^{60}$ de Gondan I a Juan Lopez Pardo, hijo de Lopo Garçia I de Villosaz, mi sobrinno. Yten mando I que le dean el fuero porqu'el esta nonbrado I en el. Yten mando que quanto a los prelbillegios que tyene mi muger, sy non I fueren contentos mis parientes que ella I los tenga, que escojan todos una prelsona fiable que los tenga en fielldade por todos. Yten fago mis I cabeçales et conplidores desta mi manda I et testamento a la dicha donna Ysabel de Castro, I mi muger, et a Roy Gonçales de Ribaldeneyra, mi sobrinno, anvos a dos I juramentados, a los quales pongo et apoldero en todos mis bienes muebeles et I rayzes para que sin mandamiento de juez nin de I alcayde ayan libre et conplido poder I para entrar et tomar tantos dellos I quantos ellos quisieren et por ben tobieren, I et los puedan vender et rematar para I que ello que ellos balieren et por ellos dieren, I cunplan et paguen todo lo contenido en este mi testa<mento >; || en speçial les dexo el dicho poder para bender el mi lulgar de Galdo que conpre a Pero de Pumarinno, I vezino de Santa Marta, que por el cunpla mientrasbasltare, et lo mas restante cunplan por todos I los otros mis bienes. Et mando desenbargar | al dicho Roy Gonçales, mi sobrinno, por su olfiçio et trabajo deste cunplimiento, et porlque le soy encargo por la parte que cabia I a su madre, el mi palaçio et vinnas I et heredades que yo tengo en Santa Maria das I Negradas. Yten

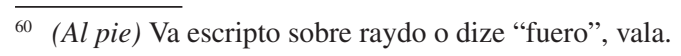


mando a Maria Lopez de Villalmayor, muger de Pero de Vibero, tres mill maravedis I en satysfaçion de lo que le soy encargo, et ruelgole por amor de Dios que me perdone lo mas. I Yten nonbro por boz del fuero del coto de I Frejulfe a Juan Nunnez Pardo, mi hijo, I para que lo aya et lieve con las bozes que tiene I despues de la muerte de la dicha donna Ysabel, I mi muger, porque hes mi boluntad que ella, en I su bida, lo llieve, et despues de su muerte I que lo aya el dicho Juan Nunnez, mi hijo. Et I mis mandas et misyones conplidas I et acabadas et debdas pagas, aviendo Icada uno lo que de suso le yo mando I por este mi testamento, en todos los otros I mis bienes muebeles et rayzes remanentes $\backslash$ $n o ? /$, I fago ${ }^{61}$ et dexo et constituyo por mis leegiltymos unibersales herederos a donna | Costança et a donna Beatris, mis legitimas || hijas et de la dicha donna Ysabel, mi muger, para I que los ayan et lieven et hereden con la venldiçion de Dios et mia, y los partan et I devidan hermanamente de por medio, I et les mando so pena de mi bendiçion, I que ellas se hamen la una a la otra como I buenas hermanas, quitando dentre sy Itodo rigor et escandalo, pleitos et leltigios et descordias, et ruego et I pido a la sennora donna Ysabel, mi muger, I que asy ge lo mande et rogue, que asy I lo cunplan, asy que esta mi boluntad. I Et esto do et otorgo por mi testamento I et ultima et protrimera boluntad conlplyda et acabada, para que se cunpla et I guarde et pague segun que de suso en <e>ste I mi testamento se contiene en todo tienpo I del mundo donde quer que paresçiere en juylzio et fuora del. Et sy alguna presona I asy de mi parte como de estranna beniere I por quebrantar et amenguar et anular I este dicho mi testamento o alguna parte del, I arredolo et apartolo de la parte quellos dichos I mis bienes aya de aver et diga que le pertelnesçer, con çinco sueldos a cada uno, I et demas caya (sic) de la voz de los dichos mis I bienes, que los no aya nin herede mas, et demas I que aya la maldiçion de Dios Padre Todolpoderoso, et $\mathrm{d}<\mathrm{e}>$ los vienabenturados I San Pedro et San Pablo, y la mia || que les non canse fasta la setima gelneraçion, et las sus animas sean I confundidas con Setan ( sic) et Abiron I et Judas el traydor en <e>l fuego ynfernal I para syenpre jamas, donde nunca ayan I redençion; et todavia et en todo tienpo I este mi testamento et ultima boluntad I balga, et que quede et este firme en su fuerça I et bigor, et todo lo que yo en $<\mathrm{e}>1$ mando, sea I fecho et conplido en todo et por todo; I et sy non baliere como testamento, ballga como codiçillo, et sy non balier como I codeçilo quiero et mando que balga I como ultima et postrimera bolluntad.

Que fue fecho et otorgado $\mid$ etc $^{62}$.

\footnotetext{
${ }^{61}$ (Al margen) "Herederos".

${ }^{62}$ (Al margen) No ay fecha.
} 
Yten desenbargo et desenpalcho a Mayor Parda, mi hermana, la I mitad del casal da Lamabella. I Yten mando que sastysfagan ha I Boliço? lo quel a mostrare, que le yo lleve I o otro por mi. Yten mando que I mis herederos et conplidores que se alcuerden et conçierten con los libros I de mis cuentas, et todo lo que se fallaren que se I debe et yo devo que me refiero a ellos I et a las escripturas autentycas et a los I albalas que paresçieren firmados. II Yten mando que Gonçalo Yanes, canonigo, llieve I un tonel de vino que yo tengo en Villajuane I en satysfaçion de una meda que le tomeen I Bilarinna (sic), et le pido perdon por amor de I de (sic) Dios.

Fecho et otorgado en la çibdad I de Villamayor, el primero dia del mes de oltubre del anno de mill et quatroçientos et I ochenta et tres annos.

\section{El Mariscal.}

Testigos que ${ }^{63} \mid$ fueron presentes, llamados et rogados:I el reberendo senor Alvaro Garçia de I Luarca, bachiller en decretos, probisor I en la yglesia de Mondonedo, et don frey I Fernando de Bolanno, ministro de la prolbinçia de Santyago, administrador I del monesteryo de Villanueba, et Fernan I Balea, canonigo, et Gonçalo Yanes I et Diego Fernandez de Labrada, canolnigos, et Roy Garçia, suchantre, et I Martin Vasquez, hijo de Martin I Vasquez, et Gil de Baracaldo, et Juan I Sanches de Carrion, clerigo de la diocesis I de Palençia, et Miguel Sanches de Bobaldilla, et Galor de Baçar, et Christobal I de Mota, et Pero Xaramillo, esculderos et criados del I rey, nuestro sennor. I

Yten yo, el dicho Mariscal, enmendando I en meu testamento a modo de codiçillo, II mando el terçio de las binnas de San Estebo, segundo I questan por la manda de mi padre Juan Parldo, que Deus aya su alma, a Juan Nunnez, mi I sobrinno, et mandole mas diez mill maravedis I para enmienda et satysfaçion de lo suyo I que comi, et demandole perdon por amor I de Dios por lo mas que enbengar la muerte I de su padre et guerras et quistiolnes yo gaste mas que por aquella I cabsa obe y mas gaste de lo mio, et manldole so pena de mi bendiçion, que no aya I mas castion (sic) I ni demanda con mis I hijas sobre esto, quel bien sabe que los Ibienes que llevaba son la mayor parte I de los bienes que mi padre avia. Yten I mando que por quanto Afonso de Santa I Marinna vino a mi et me dixo que cogiera I por mi las alcabalas de Bale et Santa I Marinna, et dize que me las pago, mando I que quanto el probare et jurare que I me pago delas, que ge las paguen, et I eso mismo quanto el mostrare que pago I de los reales del honbre que morio en I Balle en la mar, que tanto le paguen sy el I probare que me los pago o lo feziere I por su juramento. Yten por I quanto yo lleve algunas cosas I de la madre de Alfonso de Vibero II de Balladolid, que mando dar a sus herederos I seys mill maravedis, et sy no fueren contentos I que se saque pes-

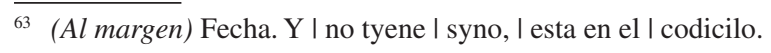


quisa, et lo que se fallare I que les soy obligado, eso les paguen. Yten I mando dar a Diego de las Riberas, por I un negro (sic) que ube de su padre, dos mill I maravedis. Yten mando que dos vacas questan en I casa de Pero, juez, en $M u$ rias (enmendado) ${ }^{64}$, que son I de Afonso Yanes de Castro, que bayan I por ellas et ge las den. Yten mando que ayan I cuenta con Alvaro do Freyxo, et sy se I fallare que yo le soy obligado de bacas I o de alguna cosa, que ge lo paguen; et quanto I a las bacas que le dio mosen Modarra, que yo I lleve, estas mosen Modarra me las dio et I por eso las tome. Yten mando darl a Juan do Naseyro, carniçero, dozentos I maravedis || que le debo de carne. Yten por quanto yo I lleve a Juan Rodrigues, clerygo do Castro d'Oro, quatro I mill maravedis, mando que ge los den et paguen. I Yten porque yo mande que Belinda, hija I de Ruy de la Camara, me pagase quatro I mill maravedis et le desocupaba çiertas I cosas, que le quiten mill del $<\mathrm{l}>\mathrm{Os}$, et sehan I tres mill maravedis los que ha de dar. Yten I mando a mi sobrinno Fernan Pardo las I mis plaças que jazen en Bibero a la I puerta de San Françisco, que jazen I enfruente de las casas que fueron de Lopo Diaz || de Pantin. I Yten mando la Juan $/{ }^{65}$ Pardo, el vastardo, I fijo de Juan Nunnez, mi herno (sic), un casal que I yo tengo en Çela, que solia llevar Diego I de Çela, y esta a la su puerta. Yten mando I et ruego a mis herederos por la mi benldiçion et so penna de mi maldiçion que non olcupen nin tomen el couto de Frejulfe a Juan I Nunne $<\mathrm{z}>$ Pardo, mi fijo, porque yo lo fize I et nonbre por voz et persona del, et mando I que moriendo el menor de hedad que quede a mis I herederos, et que a la muerte de mi muger lque lo llieve Alonso Abade, fasta quel sea I de hedad. Yten mando satysfazer a los I herederos de Ruy Diaz et Lope Lopez I et Diego Texero quatro caballos, lo que I fuere razonable. Yten mando I que I por quanto Tomas dize que yo le soy I encargo de çiertos maravedis que le tome, et mis I honbres por mi mandado, que lo quel probare I le satysfagan. Yten mando que por I quanto en el fuero de (sic) porque mi fija donna Biatris (enmendado) I esta nonbrada por persona en $<\mathrm{e}>1$, que yo asy | la nonbro et ge lo desenbargo. Yten I por quanto yo soy encargo a muchas I personas que me no acuerdo para mandar I satysfazer a cada uno partycularlmente, que yo mando que los que mostraren I que yo les soy encargo, que mis herederos le salltisfagan por mis bienes, et no lo queriendo ellos I asy fazer, non querendo açebtar mis bienes I et herençia, que yo hago et ynistituyo por I herederos mios a aquellos que ansy soy I encargo fasta que sean pagos.

El malriscal.

Et fue otorgado este codiçillo a I tres de otubre por el dicho senor I Mariscal, anno de mill et quatroçentos et $I$ ochenta et tres annos.

\footnotetext{
64 (Al pie) Va sobrerraydo o dize "Murias", vala

65 (Al pie) Va ençima del primero ringlon o dise "Juan", et sobrerraydo o dise "dona Beatris", vala.
} 
Testigos: Ares Peres, I prior de San Martinno, et Fernand Balea, calnonigo, et Gil de Baracaldo, et Fernand de I Balera, et otros.

Et eu, Diego Peres, notario I publico dado do sennor obispo de Mondolnedo en a çibdad de Villamayor et en todas I las otras billas et logares de su I obispado, a todo lo sobredicho con os I ditos testigos presente fue $<$ a $>$ este testalmento, con sus $c$ (tachado) clausolas et codiçillo I por ante outro fize escripvir, et por ende I puje aqui meu nome et syno acostumado, I en testimonio de verdade que tal he rogado I et requerido para ello.

Va escripto en tres follas I de papel con esta en que bay meu nome I et sygno.

Diego Peres, notario.

De I qual dicho testamento asy presentado antel I dicho sennor corregidor, luego la sobreldicha dona Ysabel et el dicho Roy Gonsales dixeron I que por quanto a ellos hera nesçesario I de se aprovechar del dicho testamento para lo prellsentar en algunos logares donde non podian I enbiar el dicho testamento original que le pedian, et I requerian les mandase dar del un treslado o dos o I mas, aquellos que nesçesarios les fuesen, a los I quales posyese su decreto et abtoridad para que I baliese et feziese fee donde quiera que pareslçiese vien, et asy et a tan conplidamiente I como sy el dicho testamento original pareslçiese. Et luego, el dicho sennor corregidor I dixo que bisto el dicho testamento ante el presenltado, et pedimiento fecho por la dicha donna I Ysabel et el dicho Roy Gonçales, quel manldaba et mando a mi, el dicho escribano, que les I sacase et diese del dicho testamento un tresllado o dos o tres o mas, aquellos que hellos I quisyesen. A los quales dixo quel ynterlponya et ynterpuso su decreto et abtoridad I judiçial para que baliese et feziese fee I donde quiera que paresçiese et presentados I fuesen asy en juyzio como fuera del I bien et asy et a tan conplidamente I como sy el dicho testamento original I paresçiese.

Tes<ti>gos que fueron presentes: el I honrado frey Pedro Martines, maestro I en Santa Theolosya et Juan Lopez I de Orosco, et Lope Alonso de Dios, noltarios, et Diego Gonçales de Muras et Lope da I Vinna, criados de la dicha donna Ysabel.

Et yo, I el dicho Pero Lopez de Sahagun, escripvano || et notario publico sobredicho, en uno con los I dichos testigos, presente fuy a todo lo sobreldicho, et por ruego de la dicha donna Ysabel et I del dicho Roy Gonçales, este treslado del I dicho testamento vien et fielmente saque I et lo con el conçerte, et de mi propia letra I lo escripvi en $<\mathrm{e}>$ stas syete fojas de quatro en pli<e $>$ go I de papel, et por ende aqui este mi signo et I nonbre fiz, que tal hes, en fee et testimonio I de verdad.

Pero Lopez, notario. 
1483, octubre, 1 y 3.- Villamayor de Mondoñedo.

Testamento y codicilo del mariscal Pedro Pardo de Cela, marido de doña Isabel de Castro, en el que instituye por legítimas y universales herederas a sus hijas doña Constanza y doña Beatriz.

VALLADOLID, ARCH, Pleitos Civiles, Escribanía de Alonso Rodríguez, caja 2595-1,papel, traslado notarial de Alonso de Villalobos, escribano y receptor de la reina en la villa de Vivero, realizado sobre el mismo ejemplar que se presentó el 2 de agosto de 1510 (véase doc. núm. 1) en la causa mantenida por don Diego Pérez de Villamuriel, obispo de Mondoñedo, y Bernaldino de Castellanos y doña Mayor de Vaamonde, su mujer, otorgado en Vivero el 21 de febrero de $\mathbf{1 5 1 4}$, castellano y gallego, letra procesal.

Testamento. $\mid$

$\int$ En o nome de Deus, amen. Sepan quantos I esta carta de testamento vieren como yo, el I mariscal Pedro Pardo de Çela, estando sano del I entendimiento et seso natural qual Dios nuestro I Sennor tebo por ben de me dar, et temendome de la I muerte, ques cosa natural, otorgo et conosco que fago I y hordeno este mi testamento enque demuestro I la mi postremer voluntad a serviçyo de Dios et I de Santa Marya, et de toda la corte çelestial, I et creo firmelmente $/ 66$ aquellas palabras que se contyenen I en el Credo yn Deun, por la qual creençia son çierto I que $<$ de $>$ la mi anima et de mi cuerpo et de mis bienes I fago estas mandas que se syguen. Prilmeramente mando et ofresco mi anima a mi I sennor Jhesu Christo, que la crio et la derrimio por la I su santysyma et muy presçiosa sangre, para I que faga della lo que faran de las animas jusltas, y de mi corpo mando a la terra onde fue I formado, et mando que sea sepultado en la yglesia I de el lugar donde yo fallesçiere de la presente I vida, et mando que como mis carnes fueren gastadas I que lyeven mis huesos a Sant Françisco de Vibero, et I los sepulten a donde jaçe Fernand Rodrigues de I Aguiar, mi visahuelo; et mando a la yglesia I onde primeramente fuese sepultado tres mill I maravedis, et al dicho monesteryo de San Françisco I de Bibero quinientos maravedis de cada un anno por | todo lo <que> ajo en a reguera de Ferrol, los quales dichos I quinientos maravedis mando que sean para reparo I de la sacristania et lybreria del dicho monesterio, II et que me digan por las festas de febrero et de I março et de agosto et de setyenbre de Nuestra I Sennora una misa cantada, por mi anima I et de mis antepasados, et otra por dia de I de (sic) Sant Françisco, et que sean çinco en el anno I para syenpre; et

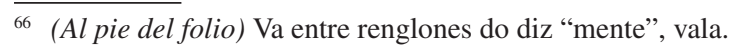


mando que me fagan mis honrras I et osequias en el dicho monesterio de Sant Françisco I de Bivero, como pertenesçe a mi honrra et estado. Yten I mando enbiar un romero a Santa Maria de Guadallupe a mi costa, et que le den un quintal de çera et I me digan ende quatro misas cantadas et veynte reçadas. Yten mando que me enbien a I Santiago d'Espanna luego como entrar el jubeleu I tres romeros, que sean personas de buena bida, et que I den a la yglesia para la obra cada romero dosentos I maravedis, et me enbien otro romero a Santa Maria I de Vilavade, et digan ende una misa cantada I et dosientos maravedis para la obra. Yten mando para reldençion de cavtibos mill maravedis. Yten a los pobres I de Sant Lazaro de Villamayor et de Vibero cada $\mid<$ un>, çinco maravedis. Yten mando el dia que me sepultaren I que den de comer a çinquenta pobres, et otros tantos I el dia que mudaren mis huesos. Yten mando que I en el fuero que yo tengo de la torre de Goyanes, I que paguen a alende de la pensyon que en el I esta, çient maravedis en cada un anno de mas, porlque syoy ( sic) encargo dello. Yten mando a Santa I Maria de Villamayor, para la vinna que oybe de donna I Mayor de Baamonde, que fue, me dygan de cada II un anno una misa cantada en dia de Santa I Marya de agosto. Yten se (tachado) mando por el I cargo que soy al monesteryo de Sant Zalvador I de Villanova, que le desocupo el fuero de I Çilleyro et Galgaon et Quende et Benbibre porque I me perdonen todo lo que del dicho monesteryo tome l et leve fasta el presente dia, et mando a mis herederos I que non lo demanden, que yo çedo el derecho que I a ellos tengo en el dicho monesteryo. Yten I desenbargo al monesteryo de Sant Martinno de I Mondonedo los benefiçios de Recadee et Cabaldin ( sic) et Sant Roman de Villaestrofee que yo I lleve del dicho monesteryo, et mando a mis helrederos, so penna de mi maldiçion, que nunca I llos demanden. Yten mando al dicho monesteryo I de Sant Martinno dos reales o sesenta maravedis de cada I un anno por lo meu casal et heredades de Marçan, I et que me digan de cada un anno una misa cantada I en dia de Sant Pero, et en su altar. Yten dexo et delsenbargo todos los benefiçios que llevava fasta I aqui a los clerigos en questavan puestos et a los I que a ellos tenian derecho, et mando a mis herederos I que non ge las ynpidan nin demanden, et pidoles I perdon por lo pasado que lleve. Yten desenlbargo la vinna de Lugoa que jas su la torre de Garçia I Mendes, que foy de Juan de Pena Mosqueyra, a Juan I de Pena Mosqueyra, seu fillo. Iten desenbargo I las vinnas que foron de Afonso Yanes, capellan do I obispo don Pedro que morava en no Castro d'Ouro, que jasen II en no coto de Canedo, a Afonso Yanes do Castro, clirigo (sic) I de Lagoa, et que lle pidan perdon por las nubidades I pasadas. Yten a Lopo Leyron mando que de I aquellas que dize que lle son encargo, que I sumarya vista (tachado $)^{67}$ mente vista su ynformaçion, I lo vea el pryor de Sant Martinno et determine lo I que fallare por derecho, et

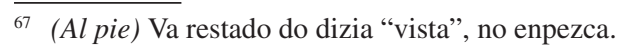


mando a mis herederos questen I por lo quel determinare, et aquello quel delxere que le pertenesçe, que aquello le desocupo. I Yten desenpacho a Fernand Valeo la otayba parte I de Santa Maria de Bretonna. Yten desenbarlgo las terreryas do Vale et das Riberas de San Selgund questan con todo lo que les pertenesçen I a meu sobrino Roy Gonçales, et que se contente con ellas I por lo mas. Yten desenbargo a minna yrmaan I Mayor Parda o qu<a $>$ rto do couto de Cajoto, que $<$ le $>$ pertenesçe I por su madre. Yten desenbargo la casa de San I Martino a los fillos de Garçia Conde, et que me paguen I çinco mill maravedis que me deven, et demanden dos mill I a Lopo de Rio que yo le torne de mas, que mande I que ge los desen. Yten desenbargo los bienes dol de Juncal de la marina de Byvero, que jasen I en Recaree, et los de Roy Martines que jasen en dicha felegrelsya, et que los lleven sus herederos et aquellos I a quien pertenesçieren de derecho. Yten desenbargo I la terrerya de Santa Cruz a la muger que fue de I Pedro de Maguarinnos, cuya ella $\mathrm{h}<\mathrm{e}>$ et le perteneslçe de derecho. Yten mando dar quinientos maravedis al molnesteryo de Santo Domingo de Bivero de una binnall que fue de frey Robeaz ( sic), que lle son obligado. Yten delsenbargo al sennor provisor el prestamo de I Fitoyro et bodos (sic) de Bretonna, por quanto conosco quel telnia et tiene a el derecho, et San Juan de Huveda, I et que aquel por quien los llevaba non tenia I justiçia. Yten desenbargo la casa et vinna de I Fernan Yanes de Requeyxo que jas en Santo Adrao al dicho I Fernand Yanes. Yten a Santa Marya a ( sic) Valdeflores I trezentos maravedis para una pitança. Yten a los I ospitales de Bibero et Villamayor, a cada uno, I diez maravedis. Yten mando a las yglesias de Galdo I et Magaços et Chavin a cada uno (sic) un calis que pelse un marco et medio de plata. Yten mando I a minna muller dona Ysabel de Castro la mi polsa de Çindymill, con todas las heredades et casalres, et con los casares de Pereyro et vinas de Valle I d'Oro et terraria de Recaree por dias de sua vida, I y despues, et (sic) quede todo desenbargo a mis herederos. I Yten por quanto desenbargo (tachado) soy obligado al I monesteryo de Sant Martinno de una casa de I refertorio que ende esta derribada, mill et I quenentos maravedis para que la reparen. Yten desenlbargo los bienes de Roy Barata a sus herederos, I o a quien pertenesçieren de derecho. Yten mando I desir en la yglesia de Villamayor tres tentanalrios por las animas de Lopo Lopes et Diego Diez I et Diego Teyxero, et mando por ellos $\backslash$ no/bezentos $<$ maravedis $>^{68}$. Yten mando a mis herederos que dexen las I casas de Bybero en que mora Pedro Lopez de Sant I Fagun al dicho Pedro Lopez por dias de sua vida, II et despues que fiique a mis herederos. Yten mando I que todos que todos (sic) los que vinieren diziendo I que yo les soy obligado et mostrare como les I soy obligado por recavdo çerto, que mis conlpridores durante su tenpo les sastyfagan, et I despues mis herederos o tal sastifagan. Yten

\footnotetext{
${ }_{68}$ (Al pie) Va entre renglones do diz "no", et emendado l et vala, et respado do dizia "desenbargo" no enlpezca.
} 
I mando que paguen al bacheler de la gralmatica Gonçalvo Garçia dos mill maravedis que le soy encargo, I et le pido por Dios que me perdone lo mas. I Yten desenbargo a Roy Vasques, canonigo, la parte del benefiçio que le cabe de Santa Çiçilia, I de quel es clerigo, con el pan de oganno que I pertenesçe <a > aquella parte de quel es clerigo. I Yten mando desenbargar a Juan de Quenlde, fillo de Juan Yannes, capellan, los bienes I que foron de su padre segund estan delsenbargados por mi carta. Yten mando I a Garçia d'Estoa, canonigo, a alende de la I otra sastifaçion que le tengo fecha, dos jornalles de vinna questan en Canedo que fueron I de Leonor de Carvallal, et que pague mill I maravedis para cunplimiento de mi testamento. Yten I çerca de la plata que Diego de Andrade que | Diego de Andrade (sic) demanda, el nunca puso I tal plata en mi mano; mi muger et Pedro Lopez I de San Fagun saben la plata que fue puesta I en mi mano, et de aquella plata mando que le saltisfagan, et lo que dello se me acuerda I es de un taçon grande que oybe de Garçia Lopez I et dile por el tres mill maravedis, et oybe otro pechel de II plata de Pedro Afonso das Seyxas, et dile por el tres I mill maravedis, et mas oybe una cadena de oro de Fernan I Peres de Andrade, et deviame por ella diez mill I maravedis, la qual cadena robaron los vezcaynos quando I entraron en Bibero; o que fuere derecho çerca desta caldena se faga, porque fue rovada a mi con I otras cosas; dize Diego de Andrade que me I pago destos maravedis non sey quantos, todo lo que I jurare aquel que dixere que me los pago, esten a su juramento, et tomenlo en cuenta de lo que me I deven de la plata de arriba, et sy en mas fuere I obligado, mas paguen mis herederos. Yten mando I que sepan de Pedro Lopez de Sant Fagun lo que I me presto Ares Pardo, et tanbien se sepa lo que I le tienen pago et reçibanlo en cuenta, et sy algo I quedare, mando que ge lo paguen. Yten mando I que paguen a Fernan Valea, canonigo, dos mill I et seysçientos et sesenta maravedis dos çinco mill que I me presto para faser la paga al sennor don Fernando. Yten I mando çerca de lo que me hera obligado Ruy Gonçales de I Tamara, canonigo, por sus bienes, que paguen quatro I mill maravedis para el conprimento de mi testamento, | et desenbargole todos sus bienes et casas para que I los aya Bilinda, su fija. Yten mando el mi fuero de I Gonta a Juan Lopez Pardo, fijo de Lope Garçia de Villaoulzas, mi sobrino, et mando que le dian el fuero porlquel esta nonbrado en el. Yten mando que quanto I a los prebillejos de Canedo que tyene mi muger, I sy non fueren contentos mis parryentes (sic), que ella II los tenga, questos $<$ co $>$ jan todos una persona fialble que los tenga en fialdade por todos. Yten I fago mis cav<eçaleyros $>$ et conplidores desta mi manda l et testamento a la dicha donna Ysabel de Castro, mi mulger, et a Roy Gonçales de Ribadeneyra, mi sobrynno, I anbos et dos juntamente, a los quales pongo et I apodero en todos mis bienes muebles et rayzes, I para que syn mandamiento de juez nin de alcalde I ayan libre poder et cunplido para entrar et tomar que tantos I dellos, quantos ellos quixeren et por bien tuvieren, I et los 
puedan vender et rematar para que de lo que I valyeren et por ellos dieren cunplan et paguen todo lo I contenido en este mi testamento; en espeçial les dexo I el dicho poder para vender el mi logar de Galdo I que conpre a Pedro de Pumarinno, vezino de Santa Marta, I et por el cunplan mientra (sic) bastare, et lo mas restante cunlplan por todos los otros mis bienes. Et mando et desenlpacho al dicho Roy Gonçales, mi sobrino, por su tralbajo et afan deste cunplimiento, et porque le soy I encargo por la parte que cabia a su madre, el mi palaçio I et vinnas et heredades que yo tengo en Santa Maria I das Vegradas (sic). Yten mando a Mari<a> Lopez de Vilalmayor, muger de Pedro de Bivero, tres mill maravedis en I sastifaçion de lo que le soy encargo, et ruegolle por amor de Dios que perdone lo mas. Yten I nonbro por vos del foro del couto de Frejulfe a Juan I Nunez Pardo, mi fijo, para que lo asa et lyelve con las vozes que tiene despues de la muerte I de la dicha donna Ysabel, mi muger, porques II mi voluntad qu'ella, en su vida, lo lieve, et despues I de su muerte que lo aya el dicho Juan Nunnez I Pardo, mi fijo. Et mis mandas et misyones conlpridas et acabadas et devdas paguas, avendo cada I uno lo que de suso le yo mando por este mi testalmento en todos los otros mis bienes muebles et I rayzes remanentes, fago et dexo et constetuyo ${ }^{69} \mid$ et estabesco por mis legitymas universales heredelras a donna Costança et a donna Beatris, mis legiltimas fillas et de la dicha donna Ysabel, mi muger, I para que los aya et lyeven et herden con la vendiçion I de Dios et mia, et los partan et devidan hermanalmente de por medio, et les mando so pena de mi I vendiçion que ellas se amen una la otra I como buenas hermanas, quitando de entre sy todo I rigor, escandalo, pleitos et letygios et dyscordias, I et ruego et pido a la sennora donna Ysabel, mi muger, I que ansy ge lo mande et ruegue que ansy lo I cunplan, ansy questa mi voluntad. Et esto do et I otorgo por mi testamento ultimo et postrimer I voluntad conplyda et acabada, para que se cunpla et I guarde et pague segund que de suso en este I mi testamento se contyene en todo tienpo del mundo I donde quiera que paresçiere en juyzio et fuera del. I Et sy alguna persona ansy de mi parte como de la I estranna veniere para quebrantar o menguar I o anular para este mi testamento o alguna I parte del, arriedolo et apartolo de la parte que de los I dichos mis bienes aya de aver et diga que le II pertenesçe, con çinco soldos a cada uno, et demas I que aya de la boz de los dichos mis bienes, que los I non aya nin herede mas, que demas que I aya la maldiçion de Dios Padre Todopoderolso et de los bienaventurados Sant Pedro et Sant I Pablo, et la mia que les non canse fasta la seltima generaçion, et las suas animas sean condelnadas con Satan et Abiron et Judas el traydor en $<$ e $>1$ fuelgo ynfernal para syenpre jamas, donde nunca aya reldençion; et todavia et en todo tienpo este mi testamenlto et hultyma et postrimera (tachado $)^{70}$ voluntad valga, et quelde et este firme en su fuerça et vigor, et

\footnotetext{
69 (Al margen) Herederos.

${ }^{70}$ (En la parte inferior) Un restado do dezia "et postrimera", no I enpeza.
} 
todo | lo que yo en <e>lla mando sea hecho et cunplido I en todo et por todo, et sy non valyere como testamento I valga como codesilo, et sy non valiere como codelsilo quiero et mando que valga como hultyma I et postrimer voluntad. Yten desenbargo et desenlpacho a Mayor Parda, mi hermana, la mitad del I casal da Lamavella. Yten mando que sastyfalgan a Voliçon ( sic) lo quel mostrar, que yo leve o I otro por min. Yten mando que mis herederos I et conplidores se acuerden et conçerten con los lybros I de mis cuentas, et todo lo que se fallare que yo I devo o me deven que me refiro a ellos en las eslcrituras autentycas et alvalaes que paresçieren I firmados. Yten mando que Garçia Yanes, calnonigo, leve un tonel de vino que eu tenno en Villaljuane en sastisfaçion de una meda que lle tomey I en Villarmea, et lle pido perdon por amor de Deus.

Que I fue fecho et otorgado en la çibdad de Villamayor I de Mondonedo, el prymero dia del mes de otubre $\|$ del anno de mill et quatroçientos et ochenta I et tres annos.

Testygos que fueron presentes, llamaldos et rogados: el reberendo sennor Alvar Garçia I de Luarca, bachiller en decretos et provisor en la I yglesia de Mondonedo, et don frey Fernando de Volanno, I ministro de la provinçia de Santyago et adlministrador del monesteryo de Villanova, et Fernan I Valea, canonigo, et Garçia Yanes et Diego Fernandes I de Labrada, canonigos, et Roy Garçia, suchanter, et Martin I Vasques, clerigo, et Gil de Varacaldo, et Juan Sanches I de Carrion, clerygo de la diocesis de Palençia, et Miguel I Sanches de Voadilla, et Galaor de Vaçan, et Christoval I de Mata, et Pedro Xaramillo, escuderos et criados del I rey, nuestro sennor.

$\int$ Et despues desto, a tres dias del dicho mes de I otubre del dicho anno de mill et quatroçientos et ochenta I et tres annos, en la dicha çibdad de Villamayor de I Mondonedo, en presençia de mi, el notario et testigos I de yuso escriptos, el dicho sennor Mariscal enmenldando en el dicho testamento en manera de codelzildo, mandoesto que se sygue: yten mas I yo, el dicho \sennor/ $/{ }^{71}$ Mariscal, enmendando en mi testamento I a modo de codeçillo, mando a terçia de las vinnas I de Santo Estebo, segundo questan en por la manda I de mi padre Juan Pardo, que Dios aya su anima, I a meu sobrinno Juan Nunnez, et mandole mas des mill I maravedis para enmenda et sastifaçion dos seus que comi, l et demandolle perdon por amor de Deus por lo mas I porque enbengar la muerte de su padre et I guerras et quistiones, en (sic) gastey mas que por aquella I| cavsa o meu, et mas gastey do meu, et mandolle sub I pena de lla mi vendiçion, que non aja mas quistion I nin demanda a mis filias sobre esto, quel I ven sabe que los lyeve (tachado $)^{72}$ bienes que lyeva son I la mayor parte de los bienes que mi padre I

\footnotetext{
71 (Al pie) Va entre renglones do diz "senor", vala.
}

72 (Al pie) Va restado do dizia "lieve", no enpezca. 
avia. Yten mando que por quanto Afonso de I Santa Marynna veo a min et me dixo que coxelra por min las alcavalas de Vale et de Santa Malrinna, et dize que me las pagou, mando que quanto I el provar et jurar que me pago dellas, que llas I paguen, et eso mismo quanto el Imostrare/ que me pagou I dos reales do ome que morreu en Vale en o mar, que tanlto le paguen sy el provar que me los pagou I o lo fizer por su juramento. Yten por quanto yo I lleve algunas cosas de casa de la madre de Allfonso de Vibero de Valladolid, que lle mando dar a sus I herederos seys mill maravedis, et sy non fueran contentos I que se saque pesquisa, et lo que se fallare que I le estoy obligado, eso les paguen. Yten mando I dar a Diego de las Riberas, por un $\operatorname{neg}^{\circ}(\text { sic })^{73}$ que I ove de su padre, dos mill maravedis. Yten mando que I duas vacas questan en casa de Pero, juez, I en Muras, que son d'Afonso Yanes do Castro, I que vayan por ellas et ge las den. Yten mando I que ayan conta con Albaro de Freyxo, et se se fallar I qu'eu lle soy obligado de vacas ou de alguna I cosa, que ge llo paguen. Et quanto a las vacas I que lle dyxo mosen Modarro que yo lleve, estas I mosen Mudarra me las dio et por eso las tome. I Yten mando del (sic) a Juan do Naseyro, carniçero, doscientos <maravedis $>$ I| que le devo de carne. Yten por quanto yo lleve a Juan I Rodrygues, clerygo del Castro d'Ouro, quatro mill I maravedis, mando que ge los den et paguen. Yten por quanto I yo mande que Vilinda, fija de Rodrigo de la Tamara, I me pagase quatro mill maravedis y le desocupava çierltas cosas, que le quito mill dellos, et sean tres I mill los qu'ella ha de dar. IYten $/{ }^{74}$ mando a meu sobrinno I Fernan Pardo las minnas praças que yazen en Bibero I a la puerta de San Françisco, que yazen en Sant (tachado) fronte I de las casas que fueron de Lopo Dias de Pantyn. I Yten mando a Juan Pardo, el vastardo, fijo de I Juan Nunnez, mi hermano, un casal que yo tenno en Çela, I que solya levar Diego de Çela, questa a sua I porta. Yten ruego et mando a mis herederos I por la mi vendiçion et so penna de maldiçion I que non ocupen nin tomen el coto de Frejulve I a Juan Nunnez Pardo, mi fijo, porque yo lo fize I et nonbre por voz et presona (sic) del, et mando que I muriendo el menor de hedad que quede a mis herelderos, et que a la muerte de mi muger que I lo lyeve Afonso Abade, fasta que el sea de I hedad. Yten mando sastyfazer a los herederos I de Ruy Dias et Lopo Lopez et Diego Texero quatro I caballos, lo que fuere razonable. Yten mando I que por quanto Tomas dize que yo le soy enlcargo de çiertos maravedis que le tome, o mis onbres I por mi mandado, que lo quel provare le sasltifagan. Yten mando que por quanto en el fuero I de Andion porque mi fija donna Beatris esta I por persona nonbrada en el, que yo ansy le nonbro II et ge lo desenbargo. Yten por quanto yo soy I encargo a muchas personas que me non acuerdo para I mandar sastifazer a cada una partycularmente, I que yo mando

\footnotetext{
${ }_{73}$ Posiblemente "negocio", definido por Sebastián de Covarrubias (1611) como "la ocupación de cosa particular que obliga al hombre a poner en ella alguna solicitud".

74 (Al pie) Va entre reglones do diz "yten", vala, I et testado do dizia "Sant" no enpezca.
} 
que los que mostraren que yo les I soy encargo, que mis herederos les sastylfagan por mis bienes, et non lo queriendo I ansy fazer o non querendo açevtar mis bienes I y herençia, que yo fago et ynistuyo (sic) por herederos mios I a aquellos que ansy soy encargo fasta que I sean pagados.

Que fue otorgado este codelçilo anno et dia et mes et lugar susoditos por el I dicho sennor Mariscal.

Testigos que fueron I presentes, llamados et rogados: Ares Peres, I prior de Sant Martinno, et Fernand Valea, canonilgo, et Gil de Varacaldo, et Fernand de Valera, et Gallaor, et otros.

Et eu, Diego Peres, notario publico I dado por do (sic) sennor obispo de Mondonedo en I a çibdade de Villamayor et en todas las otras I villas et lugares do seu obispado, a todo lo susodicho I con los ditos testigos presente fuy en este testalmento, por otro fize escrevir por ruego I et mandado et a pedimiento de Ruy Gonçales I de Ribadeneyra, et por ende puje aqui I meu nome et sygnal acostumado, en I testimonio de verdade, rogado et requelrido para ello.

Diego Peres, notario.

$\int$ Et en las espaldas del dicho testamento I está un escrito et asinado lo que sygue: ॥

Fue presentado en Santyago, a dos dias I del mes de agosto de mill et quinientos I et diez annos en avdiençia.

$\int$ En la çibdad de Santyago, a nueve dias I del mes de setyenbre de mill et quinientos et diez I annos.

$\int$ Ante mi, Jua $<$ n $>$ Nieto, et firmado de una firma.

$\int$ Testamento oreginal de Pedro Pardo, el mariscal, I presentado por Vernaldino de Castellanos. 


\section{BIBLIOGRAFÍA}

Aponte, Vasco de, Recuento de las casas antiguas del Reino de Galicia, Introducción y edición crítica a cargo del Equipo de Investigación "Galicia hasta el 1500" integrado por Manuel Díaz y Díaz et al., Santiago de Compostela, Consellería da Presidencia, Servicio Central de Publicacións, 1986.

Ariès, Philippe, El hombre ante la muerte, Madrid, Taurus, 1983.

Cal Pardo, Enrique, Catálogo de los documentos medievales, escritos en pergamino, del Archivo de la Catedral de Mondoñedo, Lugo, Diputación Provincial, 1990.

Cal Pardo, Enrique, Colección Diplomática medieval do Arquivo da Catedral de Mondoñedo, Santiago de Compostela, Consello da Cultura Galega, 1999.

Cal Pardo, Enrique, El monasterio de San Miguel de la Isla de la Colleira. Colección Documental, Lugo, [s.n.], 1983.

Cal Pardo, Enrique, El monasterio de San Salvador de Pedroso, en tierras de Trasancos. Colección documental, La Coruña, Diputación Provincial, 1984.

Cal Pardo, Enrique, Episcopologio Mindoniense, Santiago de Compostela, Instituto de Estudios Gallegos "Padre Sarmiento", CSIC-XuGa, 2003 (Cuadernos de Estudios Gallegos. Anejo 23).

Canedo, Lino, "Guevara, obispo de Mondoñedo", Archivo Ibero-Americano. Estudios acerca de Fray Antonio de Guevara en el IV centenario de su muerte, 6 (abril-septiembre.1946), págs. 283-330.

Colección de documentos históricos del Boletín de la Real Academia Gallega, La Coruña, Real Academia Gallega, 1915, vol. I.

Colección Diplomática de Galicia Histórica, Santiago de Compostela, Tipografía Galaica, 1901.

Commission Internationale de Diplomatique et Commission Internationale de Sigillographie, Diplomatica et Sigillographica: travaux préliminaires de la Commission Internationale de Diplomatique et de la Commission Internationale de Sigillographie: pour une normalisation internationale des éditions de documents et un Vocabulaire international de la Diplomatique et de la Sigillographie, Zaragoza, Cátedra Zurita de la Institución Fernando el Católico, d.l. 1984 (Folia Caesaraugustana, 1).

Ermida Meilán, Xosé Ramón, "Pardo de Cela, un capítulo da revolta galega", en Terra e tempo, 10 de septiembre de 2013.

Fernández Suárez, Gonzalo Francisco, La nobleza gallega entre los siglos XIV y XV, Santiago de Compostela, El Eco Franciscano, 2002.

García Oro, José y Portela Silva, María José, La casa de Altamira durante el Renacimiento, Santiago de Compostela, El Eco Franciscano, 2003.

Lucas Álvarez, Manuel, "Paleografía gallega. Estado de la cuestión”, Anuario de Estudios Medievales, 21 (1991), págs. 419-470.

Lucas Álvarez, Manuel, "Para unas normas complementarias de transcripción de documentos en gallego", Cuadernos de Estudios Gallegos, 12 (1949), págs. 95-110. 
Martín Cea, Juan Carlos "El modelo testamentario bajomedieval castellano y su reflejo en los diferentes grupos sociales", Edad Media. Revista de Historia, 6 (2003-2004), págs. 103-156.

Normas de transcripción y edición de textos y documentos, Madrid, Escuela de Estudios Medievales, CSIC, 1944

Pardo de Guevara y Valdés, Eduardo, "Documentos medievales de Betanzos (I). Los Pardo de Cela del siglo XV", Anuario Brigantino, 9 (1986), págs. 23-30.

Pardo de Guevara y Valdés, Eduardo, "El mariscal Pardo de Cela. Una injusticia ejemplar", Torre de los Lujanes, 55 (2005), págs. 83-108.

Pardo de Guevara y Valdés, Eduardo, "El mariscal Pardo de Cela. Leyenda, mito y realidad", en M. Alfonso Valín Valdés et al. (coord.), O Mariscal Pardo de Cela e o seu tempo. I Xornadas de Historia medieval da Mariña Lucense, Lugo, Diputación provincial, 2006, págs. 1-63.

Pardo de Guevara y Valdés, Eduardo, "Fonseca, Moscoso... y el Rey. A propósito de la accidentada peregrinación de León de Romisthal, barón de Blatna", en Os Capítulos da Irmandade. Peregrinación y conflicto social en la Galicia del siglo XV, Xunta de Galicia, Santiago de Compostela, 2006, págs. 484-501.

Pardo de Guevara y Valdés, Eduardo, "La pacificación de Galicia por los Reyes Católicos. El hecho que Zurita llamó la doma y castración del Reino de Galicia”, en Os Capítulos da Irmandade. Peregrinación y conflicto social en la Galicia del siglo XV, Santiago de Compostela, Xunta de Galicia, 2006, págs. 438-465.

Pardo de Guevara y Valdés, Eduardo, "La rebelión irmandiña. Conexiones, hechos y documentos", en Os Capítulos da Irmandade. Peregrinación y conflicto social en la Galicia del siglo XV, Santiago de Compostela, Xunta de Galicia, 2006, págs. 384-411.

Pardo de Guevara y Valdés, Eduardo, De linajes, parentelas y grupos de poder. Aportaciones a la historia social de la nobleza bajomedieval gallega, Fundación Cultural de la Nobleza Española y CSIC, Madrid, 2012.

Valera, Mosén Diego de, Crónica de los Reyes Católicos, edición y estudio por Juan de M. Carriazo, Madrid, Junta para Ampliación de Estudios. Centro de Estudios Históricos, 1927 (Revista de Filología Española. Anejo, 8). 